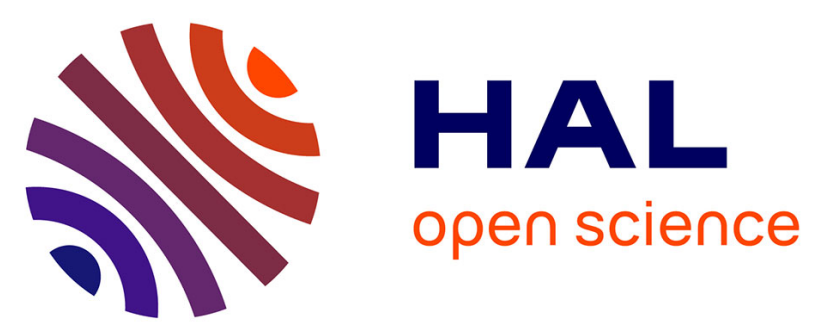

\title{
Gigantism among Late Jurassic limulids: New ichnological evidence from the Causses Basin (Lozère, France) and comments on body-size evolution among horseshoe crabs
}

Jean-David Moreau, Emmanuel Fara, Georges Gand, Gérard Lafaurie, Louis Baret

\section{To cite this version:}

Jean-David Moreau, Emmanuel Fara, Georges Gand, Gérard Lafaurie, Louis Baret. Gigantism among Late Jurassic limulids: New ichnological evidence from the Causses Basin (Lozère, France) and comments on body-size evolution among horseshoe crabs. Geobios, 2014, 47 (4), pp.237-253. 10.1016/j.geobios.2014.06.005 . insu-01061091

\section{HAL Id: insu-01061091 https://hal-insu.archives-ouvertes.fr/insu-01061091}

Submitted on 5 Sep 2014

HAL is a multi-disciplinary open access archive for the deposit and dissemination of scientific research documents, whether they are published or not. The documents may come from teaching and research institutions in France or abroad, or from public or private research centers.
L'archive ouverte pluridisciplinaire HAL, est destinée au dépôt et à la diffusion de documents scientifiques de niveau recherche, publiés ou non, émanant des établissements d'enseignement et de recherche français ou étrangers, des laboratoires publics ou privés. 


\title{
Gigantism among Late Jurassic limulids: new ichnological evidence from the Causses Basin (Lozère, France) and comments on body-size evolution among horseshoe crabs *
}

Jean-David Moreau ${ }^{\text {a, }}$, Emmanuel Fara ${ }^{b}$, Georges Gand ${ }^{b}$, Gérard Lafaurie ${ }^{c}$, Louis Baret ${ }^{d}$

a Laboratoire Géosciences, CNRS UMR 6118, Université de Rennes 1, Campus de Beaulieu bât. 15, 263 Avenue du Général Leclerc, 35042 Rennes, France.

${ }^{\mathrm{b}}$ Laboratoire Biogéosciences, CNRS UMR 6282, Université de Bourgogne, 6 Boulevard Gabriel, 21000 Dijon, France.

${ }^{\text {c }} 10$ rue Léon Baraillé, 46100 Figeac, France.

${ }^{\mathrm{d}}$ Association Paléontologique des Hauts Plateaux du Languedoc, 14 Chemin des Ecureuils, 48000 Mende, France.

* Corresponding editor: Davide Olivero.

* Corresponding author; e-mail address: jean.david.moreau@gmail.com (J.-D. Moreau)

\begin{abstract}
An abundant ichnological material composed of xiphosuran trackways and isolated traces was discovered in Upper Jurassic limestones from the Causses Basin (Causse Méjean, Lozère, France). The morphology of the imprints supports their identification as Kouphichnium isp. In contrast to the most frequent case, the trackways are composed of omnipresent pusher imprints sometime associated with leg traces, but with no telson mark. We argue that this pattern reflects actual surface traces rather than an incomplete set of undertracks. The size distribution of the sampled ichnites is broadly bimodal. This is best explained by sexual dimorphism, a phenomenon frequently observed in modern xiphosurans. Analysis of the trace fossils further suggests that several growth stages are recorded and that the horseshoe crabs were walking in a protected and flat environment like a lagoon. This area,
\end{abstract}


certainly close to a mating ground, was occasionally affected by a continental influence. The biometric study of the tracks suggests a gigantic size for the trackmakers whose body may have reached $84 \mathrm{~cm}$ in length. This discovery complements the few reports on other gigantic horseshoe crabs in the Jurassic of Western Europe, thus casting doubt on the postulated increase in body size from the Palaeozoic to the Recent. Furthermore, a literature review shows that there are still major gaps in the record of limulid body-fossils and tracks. Thus, neither of these archives can be taken at face value for quantifying the body-size evolution of horseshoe crabs.

Keywords:

Limulid traces

Xiphosura

Kouphichnium

Late Jurassic

Causses Basin

Body size

\section{Introduction}

Horseshoe crabs (Merostomata, Xiphosura) are known since the Palaeozoic (e.g., Rudkin et al., 2008) and are represented by four modern species (Sekigushi and Shuster, 2009; Obst et al., 2012). Their body fossils have a sporadic but broad geographical and stratigraphical distribution (Table 1). Their traces, most frequently assigned to the ichnogenus Kouphichnium (Nopsca, 1923), also occur sporadically on nearly all continents in rocks dated from the Late Devonian to the Oligocene (Table 1). Although Fernández and Pazos (2013) mentioned the relative scarcity of Mesozoic xiphosuran trace fossils, many occurrences of Kouphichnium are known from that time span (Table 1); recent discoveries further confirm the abundance of this ichnotaxon in the Mesozoic geological record (Pieńkowski and Niedźwiedzki, 2009; Gaillard, 2011; Diedrich, 2011; Fernández and Pazos, 2013; Peyre de Fabrègues and Allain, 2013). In this context, Late Jurassic occurrences of Kouphichnium are particularly significant for at least three reasons:

- Several of those occurrences are extremely well-documented in Fossil-KonservatLagerstätten, such as the famous mortichnial trackways associated with its trackmaker Mesolimulus walchii (Desmarest, 1817) from the Solnhofen 
Lithographic Limestones Formation (Desmarest, 1822; Maltz, 1964; Lomax and Racay, 2012);

- The Jurassic is the period during which the extant clade Limulinae von Zittel appeared in Europe, before being biogeographically isolated from its sister-group Trachypleinae Pocock at the dawn of the Cretaceous (Shishikura et al., 1982; Schuster, 1982);

- Gigantic trackways have been reported from Upper Jurassic Lagerstätten in Germany (Schweigert, 1998; Schweigert and Dietl, 2002) and France (Gaillard, 2011), thus questioning the supposed general increase in xiphosuran body size from the Palaeozoic to the Recent (Størmer, 1952; Diedrich, 2011).

Here we report on a new and abundant ichnological material composed of xiphosuran trackways and isolated traces that were discovered in upper Kimmeridgian/lower Tithonian strata from the Causses Basin (Lozère, France). This material is the first evidence of Late Jurassic xiphosurans in this region and it shows that some of these animals had a gigantic body size. The aims of this study are: (i) to characterize and to identify these traces, and (ii) to discuss their size and morphology based upon a quantitative analysis in order to better define the ecological features of Late Jurassic horseshoe crabs.

\section{Geographical and geological setting}

The ichnofossils were discovered in upper Kimmeridgian/lower Tithonian sediments of a quarry located $5 \mathrm{~km}$ east of Hures-la-Parade and that is not accessible anymore. It is located south of the Massif Central, in the Causses Basin (Causse Méjean, France; Fig. 1). In this area, the upper Kimmeridgian/lower Tithonian strata are divided in two units (Brouder et al., 1977; Gèze et al., 1980). The first one corresponds to white bioclastic limestones, locally and partially dolomitized, containing serpulids, bivalves and brachiopods (e.g., Zeilleria humeralis Roemer). The second one is composed of grey dolomites and rare coral limestones or local white-to-pink sublithographic limestones (Brouder et al., 1977). The ichnofossils described here were found in this latter lithological unit that is very homogenous and isopach. Fossils are rare as only some ammonites, belemnites, bivalves, echinids, fishes, crustaceans and terrestrial plants were reported and preserved as compressions. One continental vertebrate (the rhynchocephalian Leptosaurus pulchellus Zittel) was reported from these sublithographic limestones of the Causse Méjean (Bousquet and Vianey Liaud, 2001). Although Brouder et al. (1977) proposed a late Kimmeridgian age for these levels, we prefer to moderate their chronostratigraphic assignment for two reasons: (i) Brouder et al. (1977) could not justify 
their proposal with biostratigraphic evidence, and (ii) we noted the occurrence of rare ammonites assignable to cf. Subplanites Spath at the top of the quarry. In the absence of any firm biochronological evidence, we thus tentatively assign a late Kimmeridgian/early Tithonian age to the trace-bearing strata. In the Hures-la-Parade quarry, the section is only constituted by sublithographic limestones, and the limulid trackways occur recurrently along the stratigraphic column (Fig. 2).Three surfaces of unit 1 yielded most of the trace fossils. In this unit, thin sinusoidal traces ascribed to the ichnogenus Cochlichnus Hitchcock (whose trackmakers are either annelid worms, nematods or larvae of dipteran insects; Hasiotis, 2004) are frequently associated with the limulid trackways.

\section{Material and Methods}

Traces were successively observed by three of us: G.L. during 1994, then L.B. and JD.M. in 2005. It was possible to localize the occurrence of imprints in the stratigraphical column but due to the activity of the quarry the samples available for study were mainly collected on isolated blocks. Thirteen trackways distributed in four large assemblages were discovered (Figs. 3-5). Assemblages are named "A" to "D" and are composed of trackways 1$6 ; 7 ; 8,9$ and 10-13, respectively. Each trace is designated by the letter of the assemblage followed by the step number. When possible, the letter " $R$ " or " $L$ " are used to indicate the side (right or left) of individual track. These ichnofossils are either preserved as convex epirelief (Assemblages A, B and D; Figs. 3, 5), or as concave hyporelief (Assemblage C; Fig. 4). Only Assemblage C was observed in situ (Unit 1; Fig. 2).

Typically, the concave ventral surface of limulid body possesses six pairs of cephalothoracic appendages (Hoeven, 1838; Seilacher, 2007; Fig. 6). The first pair corresponds to the chelicerae and the second to the pedipalps. Pairs III, IV and V are walking legs and are morphologically similar to the pedipalps. They are constituted of six segments: the coxa, trochanter, femur, patella, tibia and tarsus. The chelicerae are smaller and are composed of three articles only. The appendages I to $\mathrm{V}$ are chelate; the tibia and tarsus form a pincer (chela) at their distal extremity. The sixth pair forms the pusher limbs or "pushers" (Abel, 1935; Caster, 1938; Seilacher, 2007) that are used by the animal to propel its body during locomotion or for digging. This pair of appendages differs morphologically from the others (Fig. 6). In most fossil and living taxa, its tarsus has four large pusher "blades" which are extended when the limb is in contact with the sediment (Fig. 6(C)). The pretarsus of the pushers is elongated and has a structure like a short pincer or "tarsal spine" on its extremity. A complete trackway of limulids would typically be composed of traces of appendages II-VI 
together with the median impression of the telson (Caster, 1938, 1944). Ichnofossils from Hures-la-Parade do not show imprint of the prosoma and of the telson (Fig. 6(A)). In contrast, traces of the pusher limbs are abundant and well-marked on trackways or as isolated tracks. Trackways are mainly constituted by pusher imprints (Figs. 3-5, 7), and only one was made by walking legs (Fig. 8(M), unit 6). A total of 85 pusher traces belong to the trackway assemblages and 61 others are isolated traces found on various floating limestone slabs. Isolated pusher traces are named "I" followed by a number. Unfortunately, the active carrying activities could not allow us to save assemblages C and D for which only photographs are now available. All other specimens are housed in the public collections of the Association Paléontologique des Hauts Plateaux du Languedoc (A.P.H.P.L., Mende, Lozère, France).

The descriptive terminology used here follows Minter et al., (2007a), and biometric parameters measured on tracks and imprints are derived from Tyler (1988) and Gaillard (2011) (Fig. 7). We also measured the length of the anterior part of the pusher tracks because their posterior ends are sometime missing.

\section{Systematic palaeontology}

Ichnogenus Kouphichnium Nopsca, 1923

Type species: Ichnites lithographicus Oppel, 1862

Diagnosis (following Häntzschel, 1975: p. W75): Heteropodous tracks of great variability; complex track consisting of two kinds of imprints: (1) two chevron-like series each of four oval or round holes or bifid V-shaped impressions or scratches, forwardly directed (made by anterior four pairs of feet); and (2) one pair of digitate or flabellar, toe-shaped or otherwise variable imprints (made by birdfoot-like "pushers" of fifth pair of feet, with their four or five leaf-like movable blades). Track with or without median drag-mark.

\section{Kouphichnium isp.}

\section{Description:}

Trackways: Right and left pusher traces of a same step are opposite (Fig. 7). Pairs form generally a repetitive motif on each step (e.g., Trackway 1 of Assemblage A and Trackway 8 of Assemblage C; Figs. 3(A-C), 4). Traces of the pusher limb overlap in one case only (trace B9 in Assemblage B; Fig. 3(D)). The biometric characterization of the tracks is given in Tables 2-4. Extreme values of internal trackway width are 105 and $188 \mathrm{~mm}$. Extreme values of external trackway width are 160 and $262 \mathrm{~mm}$. Strides have a wide range of values (26-334 mm). The stride is often constant within the trackways (Assemblage A, Trackway 6; 
Fig. 3(A-C)), but it can be heterogenous in rare instances (Table 4; e.g., Assemblage D, Trackway 10; Fig. 5). For example, Trackway 10 shows a doubling of the second step on the left side (D2L and D2L').

Pusher and leg traces: The trackway only composed by leg imprints (Fig. 8(M)) shows that ichnites formed thin traces disposed perpendicularly to the trackway axis. The bifid extremities of the imprints are disposed externally to the track. On pusher trackways, leg traces are constituted by a thin line with an anterior bifid part forming an acute angle open toward the front of the track. This bifid part is the imprint of the pincer of walking legs. The association of leg and pusher traces is only and partially present on Assemblages A (Trackway3; Fig. 3).

Biometric values of pusher traces are synthesized in Tables 5 and 6. Although the width of these traces is rather constant within the trackways (Table 4), the imprints of pusher limbs are heterogeneously preserved along a same trackway (e.g., Trackway 10; Fig. 5). The anterior part of individual pusher imprints is constituted by the four triangular or digit-like marks of the pusher blades (Figs. 7, 8). In some traces, the two central digit-like marks are shorter and tend to be fainter than the external ones (Fig. 8(A-L)). This ichnological pattern is in agreement with the anatomy of the pusher limb (Fig. 6(C)). Blade imprints are sometime slightly curved and oriented inwardly (e.g., Trackways 7 and 9; Figs. 3, 4). The posterior part of the pusher trace is an elongated and thin furrow made by the tarsus. This posterior mark is absent in 26\% ( $\mathrm{n}=146)$ of pusher traces (e.g., Assemblages A and C; Trackways 2 and 8; Figs. 3, 4). The extremity of the furrow is generally bifid as it corresponds to the imprint of the pretarsus.

\section{Discussion}

\subsection{Taxonomic assignment}

The morphology of the tracks from the Causses Basin shares many similarities with the xiphosuran locomotion traces firstly named Ichnites lithographicus by Oppel (1862) and later named Kouphichnium lithographicum by Nopsa (1923). In France, beside some rare reported occurrences in the Carboniferous (Racheboeuf et al., 2002; Crônier and Courville, 2005) and the Triassic (Gall, 1971), xiphosurans are only documented in the Cerin Lagerstätte (southern Jura Mountains, late Kimmeridgian/early Tithonian) by a few body fossils and one limulid trackway (Gall et al., 1996; Gaillard, 2011), as well as by a Tithonian trackway from Canjuers, southeastern France (Peyre de Fabrègues and Allain, 2013). All these late Jurassic traces were assigned to Kouphichnium. This ichnogenus was also reported from the 
contemporaneous sites of Nusplingen, Germany (Schweigert, 1998; Schweigert and Dietl, 2002) and from the Morrison Formation, USA (Hasiotis, 2004).

Kouphichnium is characterized by strongly heteropodous tracks that might show a large variety of shapes (Oppel, 1862; Nopsca, 1923; Caster, 1938; Malz, 1964). In contrast, the repichnia from the Causses Basin have a rather homogeneous morphology. The trackways and traces from Hures-la-Parade are morphologically similar to the Kouphichnium trackways from Cerin and Canjuers, France (Gaillard, 2011; Peyre de Fabrègues and Allain, 2013). The material from Cerin corresponds to a single trackway with leg and pusher imprints assigned to Kouphichnium lithographicum. The biometric characteristics of the pusher traces from Cerin are close to those described here. However, pending a comprehensive taxonomic revision of limulid traces and of the numerous species of Kouphichnium, we refrain ourselves from assigning our material to an ichnospecies and refer it to Kouphichnium isp. We agree with many other authors who suggested a whole revision of this ichnogenus and its ichnospecies (e.g., Buatois et al., 1998; Romano and Whyte, 2003; Lucas et al., 2006; Lucas and Lerner, 2005; Gaillard, 2011; Fernández and Pazos, 2013).

\subsection{Size of the trackmakers}

Fig. 9 shows the broad range of size for the pusher traces whose total length varies from 11 to $69 \mathrm{~mm}$ (Tables 5, 6). This distribution is coarsely bimodal, as observed in several fossil and recent limulid trackways or populations (Caster, 1938; Tyler, 1988; Penn and Brockmann, 1995; Smith et al., 2009). Except one small trace $11 \mathrm{~mm}$ long, the first cluster forms a rather continuous distribution of pusher lengths comprised between $17 \mathrm{~mm}$ and $c a$. $50 \mathrm{~mm}$. After a gap between $50 \mathrm{~mm}$ and $60-65 \mathrm{~mm}$, there is second, more contracted cluster of pusher tracks whose lengths are essentially comprised between $65 \mathrm{~mm}$ and $70 \mathrm{~mm}$ (Fig. 9). The large extent of the first cluster may be interpreted as representative of various growth stages. The presence of two clusters certainly reflects the sexual dimorphism in body size frequently observed among modern horseshoe crabs, females being about one third larger than males (Caster, 1938; Shuster, 1982; Smith et al., 2009). Consequently, the first cluster was probably made by individuals of both sexes at various growth stages and by adult males, whereas the second cluster probably represents adult females.

According to Malz (1964), the size of the trackmaker can be deduced from the external width (= Ex.W) of a limulid trackway (Fig. 7). For the extant Limulus polyphemus Linnaeus, the width of the prosoma and the total length of the body are respectively 1.50 and 2.12 times longer than Ex.W (Malz, 1964); these ratios are similar for other modern limulids 
(Sekiguchi, 1988). Such a simple calculation yields an estimated prosomal width of 24.0 to $39.3 \mathrm{~cm}$ and a body length of 50.9 to $83.3 \mathrm{~cm}$ for the trackmakers of the Hures-la-Parade quarry. These large values are close to those reported by Gaillard (2011) for the trackway of Cerin (estimated body length: 77.4 to $85.1 \mathrm{~cm}$ ) and higher than those of most modern limulids. If the report by Goldring and Seilacher (1971) on Early Jurassic traces (Lias of Plochingen, Germany) made by $40 \mathrm{~cm}$-wide limulids can be confirmed, it would be, to our knowledge, the oldest occurrence of very large limulid traces. It seems that the epicontinental seas of Western Europe were locally favorable to gigantic limulids during the Late Jurassic (Schweigert, 1998; Schweigert and Dietl, 2002; Gaillard, 2011; this study). In turn, these very large tracks contradict the idea of a progressive size increase for limulids over geological times (Størmer, 1952; Diedrich, 2011). In order to explore this issue further, we synthetized 90 published papers in which the width of prosoma and/or trackways were reported for Phanerozoic horseshoe crabs (Table 1; Fig. 10). Direct measures of prosomal width (black bars and dots in Fig. 10) suggest that the maximal size has increased through time. However, this pattern cannot be interpreted as a genuine evolutionary trend for several reasons. First because the values include different ontogenetic stages, males and females, as well as freshwater $v s$. marine taxa (the formers, which were smaller than the latters, became extinct in the Jurassic; Hauschke and Wilde, 1991). Second because most extant horseshoe crabs have a prosomal width comprised between 10 and $30 \mathrm{~cm}$, and they rarely reach $35 \mathrm{~cm}$ or more. Third because the limulid track record is at odd with the data provided by body fossils (Fig. 10). The gigantic Jurassic trackways are nearly twice as large as the largest limulid body-fossils known for this geological period, and the corresponding estimated prosomal width is close to $50 \mathrm{~cm}$ (dotted line in Fig. 10). The absence of recorded trackways for the entire Neogene is also noteworthy. Overall, these data show that there are major gaps in the record of limulid body-fossils and tracks, and that neither of these archives can be taken at face value for quantifying the body-size evolution in this clade. The tracks from Hures-la-Parade support the view that a gigantic size may have been frequent among some Tethyan horseshoe crabs in the Late Jurassic.

\subsection{Taphonomic and palaeoethological implications}

The variability of trace fossils arises from the complex combination of taphonomic and palaeoethological factors, and the highly variable Kouphichnium is no exception (Caster, 1938; Goldring and Seilacher, 1971; Häntzschel, 1975; Buatois and Mángano, 2011). The limulid trace fossils from the Hures-la-Parade quarry are characterized by the systematic 
presence of pusher imprints, the rarity of leg imprints, and the absence of prosoma and telson mark. How to explain such a pattern? Goldring and Seilacher (1971) warned that the best preserved arthropod tracks may represent undertracks rather than true tracks for taphonomic reasons. Indeed, traces left at the water-sediment surface may be instable and easily erased by water movements. In contrast, undertracks may be better preserved but they usually record only a part of the original trackway due to undertrack fallout, that is, the appendices having the shallowest contact with the substratum are not preserved in deeper laminae (Goldring and Seilacher, 1971). This taphonomic scenario is consistent with the preservational features of the imprints described here and that could therefore be interpreted as a repichnia made of an incomplete set of undertracks. However, two main arguments can be put forward to moderate this interpretation. First, it does not consider the probable presence of microbial mats developed at the sediment surface and that plays a crucial role in the preservation of many types of original trackways. Although such a microbially-induced preservation of true tracks still needs to be confirmed for the lithographic limestone of the Hures-la-Parade quarry, it has already been reported for the analogous site of Cerin (Gaillard, 2011) and for sedimentologically distinct Kouphichnium-bearing sites (e.g., Fernández and Pazos, 2013). Second, genuine pusher-only trackways are known to be produced by extant horseshoe crabs as a direct consequence of behavioral rather than taphonomical factors. For example, Caster (1938) and Gaillard (2011) observed that modern horseshoe crabs produce such trackways while speeding up their demersal swimming or walking. During propulsion, the anterior appendages are retracted, the body weight is supported by the pusher limbs whose imprints are generally sharp and can even be made by the four anterior blades only (Lessertisseur, 1955; Tyler, 1988; Romano and Whyte, 2003). Such a pattern is consistent with the trackways and isolated tracks from the Hures-la-Parade quarry: pusher imprints predominate, their posterior part is not recorded in $26 \%$ of cases, and they are rarely associated with imprints of other walking legs. This is very similar to the trackway from Cerin described by Gaillard (2011). This author attributed these surface or sub-surface traces to a limulid walking vigorously on the sea-floor. We concur with his interpretation and we argue that it also applies to the ichnites described here. Fig. 11 shows that for strides of comparable dimensions, the widths of pusher tracks recorded in the Causses Basin and in Cerin are similar. The great heterogeneity of strides observed between the different trackways from Hures-la-Parade may be explained by a large range of body size (Table 4). However, Fig. 11 shows that the relation between the strides and the pusher dimensions is not linear. The long strides are associated with pushers having a medium size (width between 32 and $43 \mathrm{~mm}$ ). 
This suggests that medium-sized horseshoe crabs may have been more vigorous or faster than larger ones.

\subsection{Palaeoenvironmental implications}

Living horseshoe crabs are ecological generalists that can live in diverse habitats mostly located on the continental shelf and up to the tidal zone (Sekigushi and Shuster, 2009). In the fossil record, limulids and their traces have been reported from a broad range of palaeoenvironments. The ichnogenus Kouphichnium was reported both from non-marine and freshwater palaeoenvironments (Hardy, 1970; Hasiotis and Dubiel, 1993; Hasiotis, 2004; Pieńkowski and Niedźwiedzki, 2009), ephemeral freshwater lakes (Pollard and Hardy, 1991; Zhang et al., 1998; Lucas et al., 2006), lagoons (Gaillard, 2011; Peyre de Fabrègues and Allain, 2013), estuaries (Lucas and Lerner, 2005), tidal flat areas (Gastaldo et al., 1989; Harris and Lacovara, 2004; Diedrich, 2011; Fernández and Pazos, 2013), and coastal plains (Romano and Whyte, 2003).

The ichnological association of horizontal traces such as Kouphichnium and Cochlichnus has been reported in tidal flat environments (Gastaldo et al., 1989).The coral facies known in the upper Kimmeridgian/lower Tithonian of the Causse Méjean (Brouder et al., 1977) and the presence of some echinoderms, ammonites and belemnites all argue in favor of a marine palaeoenvironment. However, the rare terrestrial fossil plants and vertebrates suppose that the area was occasionally open to continental influences. Jarzembowski (1989) noted that xiphosurid traces are often present in poorly fossiliferous strata, and this is the case in the Hures-la-Parade quarry too. The lithographic nature of the limestones supports the hypothesis of a protected environment like a lagoon or a bay. The numerous occurrences of traces along the stratigraphic column suggest that this area was close to a regular mating ground, as was probably the case for many other Kouphichnium assemblages (Caster, 1938; Diedrich, 2011; Fernández and Pazos, 2013).

\section{Conclusion}

The Upper Jurassic fossil traces from the Hures-la-Parade quarry can be confidently assigned to Kouphichnium isp. This is the first evidence of this heteropodous ichnotaxon in the Causses Basin. Although Kouphichnium is fundamentally characterized by a great variability, the reported tracks and trackways have a homogenous morphology as most of them show omnipresent and well-preserved pusher imprints. We suggest that this pattern reflects the actual surface or sub-surface traces rather than an incomplete set of deep 
undertracks. The biometric study of these traces suggests a gigantic size for the trackmakers whose body length may have reached $84 \mathrm{~cm}$. This discovery complements a few other reports of contemporaneous gigantic horseshoe crabs in Western Europe, thus casting doubt on their postulated increase in body size from the Palaeozoic to the Recent. These traces likely represent various growth stages as well as sexually dimorphic adult limulids. Analysis of the trace fossils suggests that the horseshoe crabs vigorously walked in a protected and flat environment like a lagoon, probably close to a mating ground.

\section{Acknowledgements}

We thank Sylvain Charbonnier and Günter Schweigert for their constructive reviews on the manuscript, as well as Gilles Escarguel for his rigorous editorial suggestions. We address our sincere thanks to Jacques Fages, the owner of the quarry and André Baret, the mayor of the municipality who gave their agreements for palaeontological sampling in the area under their care. We thank Norbert Hauschke, Dean Lomax, Ruth Carmichael, James Lamsdell, Günter Schweigert and Ronan Allain who kindly shared bibliographic references and data with us.

\section{References}

Abel, O., 1935. Vorzeitliche Lebensspuren. Gustav Fischer Verlag, Jena.

Allen, J.G., Feldmann, R.M., 2005. Panduralimulus babcocki n. gen. and sp., a new limulacean horseshoe crab from the Permian of Texas. Journal of Paleontology 79(3), 594-600.

Anderson, A.M., 1975. Limulid trackways in the late Palaeozoic Ecca sediments and their palaeoenvironmental significance. South African Journal of Science 71, 249-251.

Anderson, L.I., 1994. Xiphosurans from the Westphalian D of the Radstock Basin, Somerset Coalfield, the South Wales Coalfield and Mazon Creek, Illinois. Proceedings of the Geologists' Association 105, 265-275.

Anderson, L.I., 1997. The xiphosuran Liomesaspis from the Montceau-les-Mines KonservatLagerstätte, Massif Central, France. Neues Jahrbuch für Geologie und Paläontologie Abhandlungen 204, 415-436.

Anderson, L.I., Dunlop, J.A., Eagar, R.M.C., Horrocks, C., Wilson, H.M., 1999. Soft-bodied fossils from the roof shales of the Wigan Four Foot coal seam, Westhoughton, Lancashire, UK. Geological Magazine 135, 321-329. 
Anderson, L.I., Horrocks, C., 1995. Valloisella lievinensis Racheboeuf, 1992 (Chelicerata; Xiphosura) from the Westphalian B of England. Neues Jahrbuch für Geologie und Paläontologie Monatshefte 11, 647-658.

Anderson, L.I., Selden, P.A., 1997. Opisthosomal fusion and phylogeny of Palaeozoic Xiphosura. Lethaia 30, 19-31.

Babcock, L.E., Merriam D.F., 2000. Horseshoe crabs (Arthropoda: Xiphosurida) from the Pennsylvanian of Kansas and elsewhere. Transactions of the Kansas Academy of Sciences 103, 76-94.

Babcock, L.E., Merriam, D.F., West, R.R., 2000. Paleolimulus, an early limuline (Xiphosurida) from Pennsylvanian-Permian Lagerstätten of Kansas and taphonomic comparison with modern Limulus. Lethaia 33, 129-141.

Babcock, L.E., Wegweiser, M.D., Wegweiser, A.E., Stanley, T.M., McKenzie S.C., 1995. Horseshoe crabs and their trace fossils from the Devonian of Pennsylvania. Pennsylvania Geology 26(2), 2-7.

Bandel, K. 1967. Isopod and limulid marks and trails in Tonganoxie sandstone (Upper Pennsylvanian) of Kansas. University of Kansas, Paleontological Contributions 19, 110.

Barthel, K.W., Swinburne, N.H.M., Conway Morris, S., 1994. Solnhofen, a study in Mesozoic palaeontology. Cambridge University press, Cambridge.

Beecher, C. E., 1904. Note on a new Permian Xiphosuran from Kansas. American Journal of Science, series 4 18, 23-24.

Bousquet, J.-C., Vianey Liaud, M., 2001. Dinosaures et autres reptiles du Languedoc, Les presses du Languedoc, Montpellier.

Brouder, P., Gèze, B., Macquar, J.C., Paloc, H., 1977. Notice explicative, carte géologique à 1/50.000 ème de la France, feuille de Meyrueis (910). BRGM, Orléans.

Buatois, L.A., Mángano, M.G., 2011. Ichnology: Organism-Substrate Intercations in Space and Time. Cambridge University Press, Cambridge.

Buatois, L.A., Mángano, M.G., Maples, C.G., Lanier, W.P., 1998. Ichnology of an Upper Carboniferous fluvio-estuarine paleovalley: The Tonganoxie Sandstone, Buildex Quarry, eastern Kansas, USA. Journal of Paleontology 72, 152-180.

Buta, R.J., Kopaska-Merkel, D.C., Rindsberg, A.K., Martin, A.J., 2005. Atlas of Union Chapel Mine invertebrate trackways and other traces. In Buta, R.J., Rindsberg, A.K., and Kapaska-Merkel, D.C. (Eds.), Pennsylvanian Footprints in the Black Warrior Basin 
of Alabama, Alabama Paleontological Society, Monograph No. 1, Birmingham, Alabama, pp. 277-337.

Caster, K.E., 1938. A restudy of the tracks of Paramphibius. Journal of Paleontology 12, 360.

Caster, K.E., 1941. Trails of Limulus and supposed vertebrates from the Solnhofen lithographic limestone. Pan-American Geologist 76, 241-258.

Caster, K.E., 1944. Limuloid trails from the Upper Triassic (Chinle) of the petrified forest national monument, Arizona. American Journal of Science 242, 74-84.

Chakraborty, A., Bhattacharya, H.N., 2012. Early Permian Xiphosurid Trackways from India. Journal of the Geological Society of India 80,129-135.

Chisholm, J.I., 1983. Xiphosurid traces, Kouphichnium aff. variability (Linck), from the Namurian Upper Haslingden Flags of Whitworth, Lancashire. Institute of Geological Sciences, Report 83/10, 37-44.

Cohen, J.A., Brockmann, H.J., 1983. Breeding activity and mate selection in the horseshoe crab, Limulus polyphemus. Bulletin of Marine Science 33, 274-281.

Crônier, C., Courville, P., 2005. New xiphosuran merostomata from the Upper Carboniferous of Graissessac Basin (Massif Central, France). Comptes Rendus Palevol 4, 123-133.

Desmarest, A.-G., 1817. Crustacés fossiles. In: Société de Naturalistes et d'Agriculteurs (Eds.), Nouveau Dictionnaire d'Histoire naturelle, appliquée aux Arts, à l'Agriculture, à l'Économie rurale et domestique, à la Médecine, etc. Tome 7 [COR-CUN]. Deterville, Paris, pp. 495-519.

Desmarest, A.-G., 1822. Les Crustacés proprement dits. In: A. Brongniart, A. G. Desmarest (Eds.), Histoire naturelle des Crustacés Fossiles, F.G. Levrault, Paris, pp. 67-142.

Diedrich, C.G., 2011. Middle Triassic horseshoe crab reproduction areas on intertidal flats of Europe with evidence of predation by archosaurs. Biological Journal of the Linnean Society 103, 76-105.

Dunbar, C.O., 1923. Kansas Permian insects Part 2. Paleolimulus, a new genus of Paleozoic Xiphosura, with notes on other genera. American Journal of Science 5 (30), 443-454.

Eagar, R. M. C., Baines, J. G., Collinson, J. D., Hardy, P. G., Okolo, S. A., \& Pollard, J. E. (1985). Trace fossil assemblages and their occurrence in Silesian (mid-Carboniferous) deltaic sediments of the Central Pennine Basin, England. In: H. A. Curran (Ed.), Biogenic structures: Their use in interpreting depositional environments. Society of Economic Paleontologists and Mineralogists, Special publications, Tulsa, Oklahoma 35, pp. 99-149. 
Eldredge, N., 1970. Observations on burrowing behavior in Limulus polyphemus (Chelicerata, Merostomata), with implications on the functional anatomy of trilobites. American Museum novitates 2436, 1-17.

Feldmann, R.N., Schweitzer, C.E., Dattilo, B., Farlow, J.O., 2011. Remarkable preservation of a new genus and species of limuline horseshoe crab from the Creataceous of Texas, USA. Palaeontology 54, 1337-1346.

Fernández, D.E., Pazos, P.J., 2013. Xiphosurid trackways in a Lower Cretaceous tidal flat in Patagonia: Palaeoecological implications and the involvement of microbial mats in trace-fossil preservation. Palaeogeography, Palaeoclimatology, Palaeoecology 375, 1629.

Filipiak, P., Krawczyński, W., 1996. Westphalian xiphosurans (Chelicerata) from the Upper Silesia Coal Basin of Sosnowiec, Poland. Acta Palaeontologica Polonica 41, 413-425. Fillmore, D.L., Lucas, S.G., Simpson, E.L., 2010. Invertebrate trace fossils in semi-arid to arid braided-ephemeral river deposits of the Mississippian middle member of the Mauch Chunk Formation, eastern Pennsylvania, USA. Palaeogeography, Palaeoclimatology, Palaeoecology 292, 222-244.

Frickhinger, K. A. 1994. Die Fossilien von Solnhofen. The fossils of Solnhofen. Goldschneck-Verlag, Korb.

Frickhinger, K. A. 1999. Die Fossilien von Solnhofen 2. The Fossils of Solnhofen. Goldschneck-Verlag, Korb.

Gall, J.-C., 1971. Faunes et paysages du Grès à Voltzia du nord des Vosges. Essai paléoécologique sur le Buntsandstein supérieur. Mémoires du Service de la Carte Géologique d'Alsace et de Lorraine 34, 1-138.

Gall, J.-C., Bernier, P., Barale, G., Bourseau, J. P., Buffetaut, E., Gaillard, C., 1996. Découverte de limules dans les calcaires Lithographiques de Cerin (Kimméridgien, france). Archaeopteryx 14, 75-81.

Gaillard, C., 2011. A giant limulid trackway (Kouphichnium lithographicum) from the lithographic limestones of Cerin (Late Kimmeridgian, France): ethological and environmental implications. Swiss Journal of Geosciences 104, 57-72.

Gastaldo, R.A., Gibson, M.A., Gray, T.D., 1989. An Appalachian deltaic sequence, northeastern Alabama, U.S.A.: biofacies-lithofacies relationships and interpreted community patterns. International Journal of Coal Geology 12, 1-33.

Gèze, B., Pellet, J., Paloc, H., Bambier, A., Roux, J., Senaud, G., 1980. Notice explicative, carte géologique à 1/50.000ème de la France, feuille de Florac (886), BRGM, Orléans. 
Goldring, R., Seilacher, A., 1971. Limulid undertracks and their sedimentological implications. Neues Jahrbuch für Geologie und Palaöntologie, Abhandlungen 137, 422442.

Groiss, J.T., 1975. Eine Spurenplatte mit Kouphichnium (Mesolimulus) walchi (Desmarest, 1822) aus Solnhofen. Geologische Blätter für Nordost-Bayern 25, 80-95.

Hamblin, A.H., Foster, J., 2000. Ancient animal footprints and traces in the Grand StaircaseEscalante National Monument, south-central Utah. Sprinkel, D.A., Chidsey, T.C., Jr. and Anderson, P.B., eds., Geology of Utah's Parks and Monuments: Utah Geological Association Publication 28, 557-568.

Häntzschel, W., 1975. Trace fossils and problematica. In: C. Teichert (Ed.), Treatise on invertebrate paleontology, part W., Miscellanea, (second edition, W1-W269).

Geological Society of America and University of Kansas Press, Boulder Colorado and Lawrence.

Hardy, P.G., 1970. New Xiphosurid trails from the Upper Carboniferous of Northern England. Palaeontology 13, 188-190.

Harris, J.D., Lacovara, K.J., 2004. Enigmatic fossil footprints from the Sundance Formation (Upper Jurassic) of Bighorn Canyon national recreation area, Wyoming. Ichnos 11, $151-166$.

Hasiotis, S.T., 2004. Reconnaissance of Upper Jurassic Morrison Formation ichnofossils, Rocky Mountain Region, USA: paleoenvironmental, stratigraphic, and paleoclimatic significance of terrestrial and freshwater ichnocoenoses. Sedimentary Geology 167, $177-268$.

Hasiotis, S.T., Dubiel, R.F., 1993. Continental trace fossils of the Upper Triassic Chinle Formation, Petrified Forest National Park, Arizona. New Mexico Museum of Natural History and Science 3, 175-178.

Haug, C., Van Roy, P., Leipner, A., Funch, P., Rudkin, D.M., Schöllmann, L., Haug, J.T., 2012. A holomorph approach to xiphosuran evolution - a case study on the ontogeny of Euproops. Development Genes and Evolution 222, 253-268.

Hauschke, N., Wilde, V., 1987. Paleolimulus fuchsbergensis n. sp. (Xiphosura, Merostomata) aus der oberen Trias von Nordwestdeutschland, mit einer Übersicht zur Systematik und Verbreitung rezenter Limuliden. Paläontologische Zeitschrift 61, 87-108.

Hauschke, N., Wilde, V., 1989. Ein Limulide aus dem Zechstein (Oberes Perm) der Korbacher Bucht (Hessen, Bundesrepublik Deutschland). Geologisches Jahrbuch Hessen 117, 17-21. 
Hauschke, N., Wilde, V., 1991. Zur Verbreitung und Ökologie mesozoischer Limuliden.

Neues Jahrbuch für Geologie und Paläontologie Abhandlungen 183, 391-411.

Hauschke, N., Wilde, V, 2008. Limuliden aus dem Oberen Buntsandstein von

Süddeutschland. Hallesches Jahrbuch für Geowissenschaften 30, 21-26.

Hauschke, N., Wilde V., Brauckmann, C., 2004. Triassic limulids from Madagascar - missing links in the distribution of Mesozoic Limulacea. Neues Jahrbuch für Geologie und Paläontologie Monatshefte 2004(2), 87-94.

Hauschke, N., Wilde V., Pietrzeniuk, E., 1992. Ein Limulide aus des Muschlkalk (mittlere Trias) von Rüdersdorf bei Berlin. Zeitschrift für Geologische Wissenschaften 20(5-6), $461-466$.

Hoeven, J.V.D., 1838. Recherches sur l'histoire naturelle et l'anatomie des limules. S. \& L. Luchtmans, Leyde.

Holland, F.D.Jr, Erickson, J.M., O’Brien, D.E., 1975. Casterolimulus: a new Late Cretaceous generic link in Limulid lineage. Studies in Paleontology and Stratigraphy. Bulletin of American Paleontology 62, 235-249.

Hunt, A.P., Lockley, M.G., Lucas, S.G., 1993. Fossil Limuloid trackways from Petrified Forest National Park, Arizona, USA. New Mexico Museum of Natural History Bulletin 3, 199-201.

Jarzembowski, E. A. 1989. Writhlington Geological Nature Reserve. Proceedings of the Geologists'Association 100, 219-234.

Kolb, A., 1963. Riesige Limulus-Fährte aus den lithographischen Schiefern bei Pfalzpaint. Geologische Blätter für Nordost-Bayern 13, 73-78.

Lee, C.N., Morton, B., 2005. Experimentally derived estimates of growth by juvenile Tachypleus tridentatus and Carcinoscorpius rotundicauda (Xiphosura) from nursery beaches in Hong Kong. Journal of experimental marine biology and ecology 318(1), $39-49$.

Leschen, A.S., Grady, S.P., Valiela I., 2006. Fecundity and spawning of the Atlantic horseshoe crab, Limulus polyphemus, in Pleasant Bay, Cape Cod, Massachusetts, USA. Marine Ecology 27(1), 54-65.

Lessertisseur, J., 1955. Traces fossiles d'activité animale et leur signification paléobiologique. Mémoire de la Société géologique de France 74, 1-150.

Lockley, M.G., Matsukawa, M., 2009. A review of vertebrate track distributions in East and Southeast Asia. Journal of the Paleontological Society of Korea 25, 17-42. 
Lomax, D.R., Racay, C.A., 2012. A long mortichnial trackway of Mesolimulus walchi from the Upper Jurassic Solnhofen lithographic limestone near Wintershof, Germany. Ichnos 19, 175-183.

Loveland, R. E., Botton, M.L., 1992. Size dimorphism and the mating system in horseshoe crabs, Limulus polyphemus L. Animal Behaviour 44(5), 907-916.

Lucas, S.G., Lerner, A.J., 2005. Lower Pennsylvanian invertebrate ichnofossils from the Union Chapel Mine, Alabama: a preliminary assessment. In Buta, R .J., Rindsberg, A. K., and Kopaska-Merkel, D. C. (Eds.), Pennsylvanian Footprints in the Black Warrior Basin of Alabama: Alabama Paleontological Society Monograph No. 1, pp. 147-152.

Lucas, S.G., Lerner, A.J., Milner, A.C., Lockley, M.G., 2006. Lower Jurassic invertebrate ichnofossils from a clastic lake margin, Johnson Farm, Southwestern Utah. New Mexico Museum of Natural History Bulletin 37, 128-136.

Malz, H., 1964. Kouphichnium walchi, die Geschichte einer Fährte und ihres Tieres. Natur und Museum 94, 81-97.

Miller, M.F., 1982. Limulicubichnus: A new ichnogenus of limulid resting traces. Journal of Paleontology 56, 429-433.

Minter, N.J., Braddy, S.J., 2009. Ichnology of an Early Permian intertidal flat: The Robledo Mountains Formation of southern New Mexico, USA. Special Paper in Palaeontology $82,1-107$.

Minter, N.J., Braddy, S.J., Davis, R.B., 2007a. Between a rock and a hard place: arthropod trackways and ichnotaxonomy. Lethaia 40, 365-375.

Minter, N.J., Krainer, K., Lucas, S.G., Braddy, S.J., Hunt, A.P., 2007b. Palaeoecology of an Early Permian playa lake trace fossil assemblage from Castle Peak, Texas, USA. Palaeogeography, Palaeoclimatology, Palaeoecology 246, 390-423.

Moore, R.A., Mc Kenzie, S.C., Lieberman, B.S. 2007. A Carboniferous Synziphosurine (Xiphosura) from the Bear Gulch Limestone, Montana, USA. Palaeontology 50, 10131019.

Nopsca, F. 1923. Die Familien der Reptilien. Fortschritte der Geologie und Paläontologie 2, $1-210$.

Nielsen, E., 1949. On some trails from the Triassic beds of East Greenland. Meddelelser om Grønland 149, 1-44.

Obst, M., Faurby, S., Bussarawit, S., Funch, P., 2012. Molecular phylogeny of extant horseshoe crabs (Xiphosura, Limulidae) indicates Paleogene diversification of Asian species. Molecular Phylogenetics and Evolution 62, 21-26. 
Oishi, H., Matsukuma, A., Aihara, A., 1993. Limulid trace fossils from the Oligocene of Takeo, Saga Prefecture, Japan. Science reprints, Department Earth and Planetary Science, Kyushu University 18, 73-84.

Oppel, A., 1862. Über Fährten im lithographischen Schiefer (Ichnites lithographicus).

Paläontologische Mittheilungen aus dem Museum des Königlich Bayerischen Staates 1, $121-125$.

Pazos, P.J., Lazo, D.G., Tunik, M.A., Marsicano, C.A., Fernández, D.E., Aguirre-Urreta, M.B., 2012. Paleoenvironmental framework of dinosaur tracksites and other ichnofossils in Early Cretaceous mixed siliciclastic-carbonate deposits in the Neuquén Basin, northern Patagonia (Argentina). Gondwana Research 22(3), 1125-1140.

Penn, D., Brockman, H.J., 1995. Age-biased stranding and righting in horseshoe crabs, Limulus polyphemus. Animal Behavior 49, 1531-1539.

Peyre de Fabrèges, C., Allain, R., 2013. A limulid trackway from the Late Jurassic (Tithonian) Lagerstätte of Canjuers (Var, France). Comptes Rendus Palevol 12(4), 181189.

Pieńkowski, G., Niedźwiedzki, G., 2009. Invertebrate trace fossil assemblages from the Lower Hettangian of Soltyków, Holy Cross Mountains, Poland. Holy Cross Mountains. Poland. Volumina Jurassica 6, 109-131.

Pickett, J.W., 1984. A new freshwater limuloid from the Middle Triassic of New South Wales. Palaeontology 27, 609-621.

Pickett, J.W., 1993. A Late Devonian xiphosuran from near Parkes, New South Wales. Memoirs of the Association of Australasian Palaeontologists 15, 279-287.

Pollar, J.E., Hardy, P.G., 1991. Trace fossils from Westphalian D of Writhlington. Geological Nature Reserve, nr. Radstock, Avon. Proceedings of the Geologists'Association 102, 169-178.

Racheboeuf, P.R., Vannier, J.,Anderson, L.I., 2002. A new three-dimensionally-preserved xiphosuran chelicerate from the Montceau-les-Mines Lagerstätte (Carboniferous, France). Palaeontology 45(1), 125-147.

Riek, E.F., Gill, E.D., 1971. A new xiphosuran genus from Lower Cretaceous freshwater sediments at Koonwarra, Victoria, Australia. Palaeontology 14, 206-210.

Romero, A., Vía Boada, L., 1977. Tarracolimulus rieki, nov. gen., nov. sp., nuevo limulido del Triásico de Montral-Alcover (Tarragona). Cuadernos de Geología Ibérica 4, 239 246. 
Romano, M., Whyte, M.A., 2003. The first record of xiphosurid (arthropod) trackways from the Saltwich Formation, Middle Jurassic of the Claveland Basin, Yorkshire. Palaeontology 46 (2), 257-269.

Rudkin, D.M., Young, G.A., Nowlan, G.S., 2008. The oldest horseshoe crab: a new xiphosurid from the Late Ordovician Konservat-Lagerstätten deposits, Manitoba, Canada. Palaeontology 51(1), 1-9

Schweigert, G., 1998. Die Spurenfauna des Nusplinger Plattenkalks (Oberjura, Schwäbische Alb). Stuttgarter Beiträge zur Naturkunde Serie B 262, 1-47.

Schweigert, G., Dietl, G., 2002. Miscellanea aus dem Nusplinger Plattenkalk (Ober-

Kimmeridgium, Schwäbische Alb.). 4. Limuliden. Jahresberichte und Mitteilungen des Oberrheinischen Geologischen Vereins NF 84, 323-331.

Seilacher, A., 2007. Trace Fossil Analysis. Springer Verlag, Berlin Heidelberg New York.

Sekiguchi, K., 1988. Biology of horseshoe crabs. Science House Co., Tokyo.

Sekiguchi, K., Shuster, C.N., 2009. Limits on the global distribution of horseshoe crabs (Limulacea): lessons learned from two lifetimes of observations: Asia and America. In: Tanacredi, J.T., Botton, M.L., Smith, D.R. (Eds.), Biology and Conservation of Horseshoe crabs. Springer, Boston, pp. 5-24.

Shishikura, F., Nakamura, S., Takahashi, K., Sekiguchi, K., 1982. Horseshoe crab phylogeny based on amino acid sequence of the firbino-peptide-like peptide C. The Journal of Experimental Zoology 223, 89-91.

Shuster, C.N., 1982. A pictorial review of the natural history and ecology of the horseshoe crab Limulus polyphemus, with reference to other Limulidae. In.: J. Bonaventura, C. Bonaventura \& S. Tesh (Eds.), Physiology and biology of horseshoe crabs. Studies on normal and environmentally stressed animals. Alan R. Liss, Inc., New York, pp. 1-52.

Siveter, D.J., Selden, P.A., 1987. A new, giant xiphosurid from the lower Namurian of Weardale, County Durham. Proceedings of the Yorkshire Geological Society 46, 153 168.

Smith, D.R., Mandt, M.T., Macdonald, P.D.M., 2009. Proximate Causes of Sexual Size Dimorphism in Horseshoe Crabs (Limulus polyphemus) of the Delaware Bay. Journal of Shellfish Research 28(2), 405-417.

Størmer, L., 1952. Phylogeny and taxonomy of fossil horseshoe crabs. Journal of Paleontology 26, 630-639. 
Tyler, D.J., 1988. Evidence and significance of limulid instars from trackways in the Bude Formation (Westphalian), south-west England. Proceedings of the Ussher Society 7, 77-80.

Vía Boada, L., 1987. Artrópodos fósiles triásicos de Alcover-Montral. II. Limúlidos.

Cuadernos Geología Ibérica 11, 281-282.

Vía Boada, L., Villalta, J.F., 1966. Heterolimulus gadeai, nov. gen., nov. sp., représentant d'une nouvelle famille de Limulacés dans le Trias d'Espagne. Compte Rendu Sommaire des Séances de la Société Géologique de France 2, 57-59.

Wang, G. 1993. Xiphosurid trace fossils from the Westbury Formation (Rhaetian) of Southwest Britain. Palaeontology 36, 111-122.

Wright, A.D., Benton, M.J., 1987. Trace fossils from Rhaetian shoreface deposits of Staffordshire. Palaeontology 30, 407-428.

Xing, L.- D., Lockley, M.G., Qind, H., Matsukawa, M., Persons IV, W.S., Xiao, Y.-W., Zhang, J.-P., 2012. Forgotten Paleogene limulid tracks: Xishuangbanania from Yunnan, China. Palaeoworld 21, 217-221.

Zhang, G., Buatois, L.A., Mangano, M.G., Acenolaza, F.G., 1998. Sedimentary facies and environmental ichnology of a ?Permian playa-lake complex in western Argentina. Palaeogeography, Palaeoclimatology, Palaeoecology 138, 221-243. 


\section{Table and Figure captions}

Table 1. Synthesis of widths measured on xiphosurid bodies and trackways from the Palaeozoic to the Recent (in $\mathrm{cm}$ ). *: Dimension estimated from published illustrations.

Table 2. Measurements of internal and external widths of trackways (in mm).

Table 3. Measurements of the strides (in mm).

Table 4. Mean and standard deviation (SD) values of stride length and width of pushers for each trackway (in mm).

Table 5. Measurements of width, total length and length of the anterior part of the pusher imprints preserved on trackways (in $\mathrm{mm}$ ).

Table 6. Measurements of width, total length and length of the anterior part of the isolated pusher imprints (in $\mathrm{mm}$ ).

Figure 1. Location and geological context of the Causses Basin. The star indicates the Huresla-Parade quarry (late Kimmeridgian/early Tithonian). Modified after Grigniac and Taugourdeau-Lantz (1982).

Figure 2. Stratigraphic occurrences of the trace-bearing surfaces. A: stratigraphic log of the Hures-la-Parade quarry. B: detail of the top of the section (lithological unit 6). L. Un., lithological units (1 to 6); L. S. Un., lithological sub-units (S1 to S21); Lith., lithology. Scale bars: $1 \mathrm{~m} \mathrm{(A),} 20 \mathrm{~cm}(\mathrm{~B})$.

Figure 3. Two assemblages bearing limulid trackways. A-C: Assemblage A, photograph and interpretation; T1-T6 = Pusher trackways 1 to $6, \mathrm{~A} 1-\mathrm{A} 26=$ step number. D: Assemblage B; $\mathrm{T} 7=$ Pusher trackway 7, B1-B26 = step number. $\mathrm{R}=$ right, $\mathrm{L}=$ left. The arrows indicate the direction of movement. Scale bars: $20 \mathrm{~cm}(\mathrm{~A}-\mathrm{C}), 10 \mathrm{~cm}$ (D). 
Figure 4. One assemblage bearing limulid trackways. A, B: Assemblage C, photograph and interpretation; T8, T9 = Pusher trackways 8 and 9, C1-C6 = step number. $\mathrm{R}=$ right, $\mathrm{L}=$ left. Scale bar: $20 \mathrm{~cm}$.

Figure 5. One assemblage bearing limulid trackways. A-C: Assemblage D, photograph and interpretation; T10-T13 = Pusher trackways 10 to 13, D1-D16 = step number. $\mathrm{R}=$ right, $\mathrm{L}=$ left. The arrows indicate the direction of movement. Scale bar: $20 \mathrm{~cm}$.

Figure 6. Anatomy of limulid appendages. A: simplified ventral view of a limulid showing the six pairs of appendages I-VI. B: left sixth appendage or "pusher limb" with blades regrouped in resting position. $\mathbf{C}$ : distal part of the sixth appendage showing the spread of pusher blades during propulsion. I, chelicerae; II, pedipalps; III, IV and V, walking legs; VI, pusher limbs. 1, coxa; 2, trochanter; 3, femur; 4, patella; 5, tibia; 6 , tarsus; Pb., pusher blades; Ts., tarsal spines.

Figure 7. Biometric characters measured on trackways and pusher traces. W, width; TL, total length; Lap, length of the anterior part; St, stride; In.W, inner width; Ex.W, external width.

Figure 8. Illustration of some traces of the sixth cephalothoracic appendage. A-L: APHPL_I2, APHPL_I8B, APHPL_I11, APHPL_I12, APHPL_I25, APHPL_I36, APHPL_I37A, APHPL_D8, APHPL_I39B, APHPL_I48, APHPL_I45, and APHPL_I49, respectively. M: APHPL_L1, trackway composed of legs only. Scale bar: $1 \mathrm{~cm}$.

Figure 9. Bivariate diagram (width vs. total length) of limulid traces from the Hures-la-Parade quarry and from Cerin (Gaillard, 2011).

Figure 10. Variation in width as measured on limulid bodies (black dots and bars) and trackways (white dots and bars) from the Palaeozoic to the Recent. The dotted line represents the maximal prosomal width inferred from the external width of trackways based on the 1.5 ratio given by Malz (1964). The measured width of the trackway from Hures-la-Parade, as well as the corresponding estimated prosomal width, are indicated by a white square and a white star, respectively. Data from the references listed in Table 1. C, Cambrian; O, Ordovician; S, Silurian; D, Devonian; C, Carboniferous; P, Permian; T, Triassic; J, Jurassic; K, Cretaceous; Pg, Palaeogene; N, Neogene; Q, Quaternary. 
Figure 11. Bivariate diagram showing the average values of pusher widths and strides for each trackway from the Hures-la-Parade quarry and Cerin (Gaillard, 2011). Dashed contour line: $95 \%$ confidence interval. 
Table 1.

\begin{tabular}{|c|c|c|c|c|c|c|}
\hline Age & Locality & Body & Trace & Body width & Trackway width & Reference \\
\hline Ordovician & Manitoba, Canada & 1 & 0 & 2.6 & - & Rudkin et al. (2008) \\
\hline Devonian & Parkes, Australia & 1 & 0 & 6 & - & Pickett (1993) \\
\hline Devonian & Pennsylvania, USA & 1 & 1 & $5^{*}$ & about $2.2 *$ & Babcock et al. (1995) \\
\hline Carboniferous & Graissessac, France & 1 & 0 & 2.5 & - & Crônier and Courville (2005) \\
\hline Carboniferous & Montceau-les-Mines, France & 1 & 0 & $0.8^{*}$ & - & Anderson (1997) \\
\hline Carboniferous & Montceau-les-Mines, France & 1 & 0 & $0.84-1.08$ & - & Racheboeuf et al. (2002) \\
\hline Carboniferous & Piesberg, Germany & 1 & 0 & $0.7-6$ & - & Haug et al. (2012) \\
\hline Carboniferous & Sosnowiec Basin, Poland & 1 & 0 & $2.0-4.8$ & - & Filipiac and Krawczyński (1996) \\
\hline Carboniferous & Bude Formation, south-west UK & 0 & 1 & - & $0.03-0.20$ & Tyler (1988) \\
\hline Carboniferous & Central Pennine Basin, UK & 0 & 1 & - & 2.8 & Eagar et al. (1985) \\
\hline Carboniferous & Country Durham, UK & 1 & 0 & 1.5 & - & Siveter and Selden (1987) \\
\hline Carboniferous & Cornwall, UK & 0 & 1 & - & ? & Goldring and Seilacher (1971) \\
\hline Carboniferous & Lancashire, UK & 0 & 1 & - & $0.16-0.17$ & Hardy (1970) \\
\hline Carboniferous & Lancashire, UK & 0 & 1 & - & 3 & Chisholm (1983) \\
\hline Carboniferous & Lancashire, UK & 1 & 0 & about $3.3^{*}$ & - & Anderson et al. (1999) \\
\hline Carboniferous & Lancashire, UK & 1 & 0 & about $3.7^{*}$ & - & Anderson and Selden (1997) \\
\hline Carboniferous & Pantyffynon, UK & 1 & 0 & up to $1^{*}$ & - & Anderson and Horrock (1995) \\
\hline Carboniferous & Writhlington, UK & 1 & 1 & less than $3^{*}$ & ? & Jarzembowski 1989) \\
\hline Carboniferous & Writhlington, UK & 0 & 1 & - & $2.5-5.0$ & Pollard and Hardy (1991) \\
\hline Carboniferous & Alabama, USA & 0 & 1 & - & $3-4$ & Lucas and Lerner (2005) \\
\hline Carboniferous & Alabama, USA & 0 & 1 & - & $2.5-7.5$ & Buta et al. (2005) \\
\hline Carboniferous & Alabama, USA & 0 & 1 & - & up to $2 *$ & Gastaldo et al. (1989) \\
\hline Carboniferous & Illinois, USA & 1 & $\begin{array}{l}1 \\
0\end{array}$ & up to $7 *$ & - & Anderson (1994) \\
\hline Carboniferous & Kansas, USA & 0 & 1 & - & $1.96-5.11$ & Buatois et al. (1998) \\
\hline Carboniferous & Kansas, USA & 0 & 1 & - & $1.3-5.5$ & Bandel (1967) \\
\hline Carboniferous & Kansas, USA & 1 & 0 & up to $7^{*}$ & - & Babcock and Merriam (2000) \\
\hline Carboniferous & Montana, USA & 1 & 0 & $2.1-2.2$ & - & Moore et al. (2007) \\
\hline Carboniferous & Pennsylvania, USA & 0 & 1 & - & $?$ & Fillmore et al. (2010) \\
\hline Carboniferous & Tennessee, USA & 0 & 1 & - & up to 11 & Miller (1982) \\
\hline Uppermost Carboniferous/Permian & Kansas, USA & 1 & 0 & up to $9^{*}$ & - & Babcock et al. (2000) \\
\hline Permian & Great Karoo Basin, Africa & 0 & 1 & - & about $8 *$ & Anderson (1975) \\
\hline Permian (?) & Western Argentina & 0 & 1 & - & $?$ & Zang et al. (1998) \\
\hline Permian & Hessen, Germany & 1 & 0 & about 15 & - & Hauschke and Wilde (1989) \\
\hline Permian & India & 0 & 1 & - & up to $9^{*}$ & Chakraborty and Bhattacharya (2012) \\
\hline Permian & Kansas, USA & 1 & 0 & ? & $-\quad-20$ & Beecher (1904) \\
\hline Permian & New Mexico, USA & 0 & 1 & - & up to 5 & Minter and Braddy (2009) \\
\hline Permian & Texas, USA & 0 & 1 & - & $?$ & Minter et al. (2007b) \\
\hline Permian & Texas, USA & 1 & 0 & up to 1.348 & - & Allen and Feldmann (2005) \\
\hline Permian & Texas, USA & 1 & 0 & 2.4 & - & Dunbar (1923) \\
\hline Triassic & Australia & 1 & 0 & 2.78 & - & Pickett (1984) \\
\hline Triassic & Vosges, France & 0 & 1 & - & $5-12$ & Gall (1971) \\
\hline Triassic & Bernburg, Germany & 0 & 1 & - & $6-10$ & Diedrich (2011) \\
\hline Triassic & Northwestern, Germany & 1 & 1 & up to 1.4 / & about 2.5 & Hauschke and Wilde (1987) \\
\hline Triassic & Rüdersdorf, Germany & 1 & 0 & 10 & - & Hauschke et al. (1992) \\
\hline Irrassic & Southern Germany & 1 & 0 & $0.8-2.9$ & - & Hauschke and Wilde (2008) \\
\hline Triassic & East Greenland & 0 & 1 & - & $3.5-7.5$ & Nielsen (1949) \\
\hline Triassic & Ankitokazo Basin, Madagascar & 1 & 0 & about 5 and 7 & - & Hauschke et al. (2004) \\
\hline Triassic & Tarragona Province, Spain & 1 & 0 & $3.1-5.3$ & - & Vía Boada 1987; Roméro and Vía Boada (1977) \\
\hline Triassic & Spain & 1 & 0 & less than 20 & - & Vía Boada and Villalta (1966) \\
\hline Triassic & Staffordshire, UK & 0 & 1 & - & $1.5-2.0$ & Wright and Benton (1987) \\
\hline Triassic & Westbury Formation, UK & 0 & 1 & - & $7-8$ & Wang (1993) \\
\hline Triassic & Arizona, USA & 0 & 1 & - & $8-10$ & Hunt et al. (1993) \\
\hline Triassic & Arizona, USA & 0 & 1 & - & $?$ & Hasiotis and Dubiel (1993) \\
\hline Triassic & Arizona, USA & 0 & 1 & - & 6.5 & Caster (1944) \\
\hline Triassic & Pinceton (New Jercey), USA & 0 & 1 & - & $?$ & Goldring and Seilacher (1971) \\
\hline Triassic & Utah, USA & 0 & 1 & - & less than $8^{*}$ & Hamblin and Foster (2000) \\
\hline Jurassic & Canjuers, France & 0 & 1 & - & $17.2-17.5$ & Peyre de Fabrèges and Allain (2013) \\
\hline Jurassic & Causses Basin, France & 0 & 1 & - & $10.0-26.2$ & This study \\
\hline Jurassic & Cerin, France & 1 & 0 & $9-16$ & - & Gall et al. (1996) \\
\hline Jurassic & Cerin, France & 0 & 1 & - & $25.7-26.0$ & Gaillard (2011) \\
\hline Jurassic & Nusplingen, Germany & 1 & 1 & 23.5 & 26 & Schweigert (1998) \\
\hline Jurassic & Nusplingen, Germany & 1 & 1 & less than $12 *$ & $?$ & Schweigert and Dietl (2002) \\
\hline Jurassic & Solhofen, Germany & 0 & 1 & - & 6.1 & Caster (1941) \\
\hline Jurassic & Solhofen, Germany & 1 & 1 & $?$ & $?$ & Goldring and Seilacher (1971) \\
\hline Jurassic & Solhofen, Germany & 1 & 1 & about 10 & about 10 & Groiss (1975) \\
\hline Jurassic & Solhofen, Germany & 1 & 1 & 9.2 & about 9 & Barthel et al. (1994) \\
\hline Jurassic & Solhofen, Germany & 1 & 1 & 23 & 33 & Frickhinger (1994) \\
\hline Jurassic & Solhofen, Germany & 0 & 1 & - & 22.5 & Kolb (1963) \\
\hline Jurassic & Solnhoten, Germany & 1 & 0 & $\because(53$ tor the length) & - & Frickhinger (1999) \\
\hline Jurassic & Southern Germany & 0 & 1 & - & $40(?)$ & Goldring and Seilacher (1971) \\
\hline Jurassic & Wintershof, Germany & 1 & 1 & 6.9 (1mmature) & 4.25 & Lomax and Racay (2012) \\
\hline Jurassic & Holy Cross Mountain, Poland & 0 & 1 & - & ? & Pieńkowski and Niedźwiedzki 2009) \\
\hline Jurassic & Rocky Montain, USA & 0 & 1 & - & ? & Hasiotis (2004) \\
\hline Jurassic & Utah, USA & 0 & 1 & - & up to 4 & Lucas et al. (2006) \\
\hline Jurassic & Wyoming, USA & 0 & 1 & - & up to $10^{*}$ & Harris and Lacovara (2004) \\
\hline Jurassic & Cleveland Basin, Yorkshire & 0 & 1 & - & $16-17$ & Romano and Whyte (2003) \\
\hline Cretaceous & Patagonia, Argentina & 0 & 1 & - & 2.5 & Pazos et al. (2012); Fernández and Pazos (2013) \\
\hline Cretaceous & Australia & 1 & 0 & 8.5 & - & Riek and Gill (1971) \\
\hline Cretaceous & Dakota, USA & 1 & 0 & 10.6 & - & Holland et al. (1975) \\
\hline Cretaceous & Texas, USA & 1 & 0 & 17.5 & - & Feldmann et al. (2011) \\
\hline Eocene & Weilßelster Basin, Germany & 1 & 0 & $17.5-29.5$ & - & Hauschke and Wilde (2008) \\
\hline Oligocene & Takeo, Japan & 1 & 0 & 24.6 & - & Oishi et al. (1993); Lockley and Matsukawa (2009) \\
\hline Palaeogene & Yunnan Province, China & 0 & 1 & - & 2.67 & Xing et al. (2012) \\
\hline Recent & $?$ & 1 & 0 & $16.6-22.0$ & - & Shuster (1982) \\
\hline Recent & East coast of North America & 1 & 0 & $3.7-5.0$ (immatures) & - & Eldredge (1970) \\
\hline Recent & Hong Kong, China & 1 & 0 & $1.71-9.11$ & - & Lee and Morton (2005) \\
\hline Recent & Seehorse Key, Flonda, USA & 1 & 0 & up to $31.1^{*}$ & - & Cohen and Brockmann (1983) \\
\hline Recent & Pleasant Bay, Massachusetts, USA & 1 & 0 & $18.5-30.0$ & - & Leschen et al. (2006) \\
\hline Recent & Delaware Bay, New Jersey, USA & 1 & 0 & $27-38$ & - & Smith et al. (2009) \\
\hline Recent & Delaware Bay, New Jersey, USA & 1 & 0 & about $13-33$ & - & Loveland and Botton (1992) \\
\hline
\end{tabular}


Table 2.

\begin{tabular}{lllll}
\hline Assemblage Trackway & Trace & Internal width & External width \\
\hline A & 1 & A1R-A1L & 140 & 214 \\
A & 1 & A2R-A2L & 148 & 227 \\
A & 2 & A5R-A5L & 105 & 160 \\
B & 7 & B5R-B5L & 147 & - \\
C & 8 & C1R-C1L & 188 & 262 \\
C & 8 & C2R-C2L & 178 & 248 \\
C & 9 & C4R-C4L & 186 & 256 \\
D & 10 & D1R-D1L & 148 & 227 \\
D & 10 & D2R-D2L & 164 & 248 \\
D & 10 & D3R-D3L & 149 & 237 \\
D & 10 & D4R-D4L & 130 & 217 \\
\hline
\end{tabular}


Table 3.

\begin{tabular}{llll}
\hline Assemblage & Trackway & Trace & Stride \\
\hline A & 1 & A1L-A2L & 152 \\
A & 1 & A2L-A3L & 185 \\
A & 1 & A3L-A4L & 215 \\
A & 1 & A1R-A2R & 195 \\
A & 3 & A6-A7 & 147 \\
A & 3 & A7-A8 & 180 \\
A & 3 & A8-A9 & 190 \\
A & 4 & A10-A11 & 334 \\
A & 4 & A11-A12 & 330 \\
A & 5 & A13-A14 & - \\
A & 5 & A14-A15 & - \\
A & 6 & A16-A17 & 52 \\
A & 6 & A17-A18 & 47 \\
A & 6 & A18-A19 & 59 \\
A & 6 & A19-A20 & 47 \\
A & 6 & A20-A21 & 47 \\
A & 6 & A21-A22 & - \\
A & 6 & A22-A23 & - \\
A & 6 & A23-A24 & 48 \\
A & 6 & A24-A25 & 48 \\
A & 6 & A25-A26 & 50 \\
B & 7 & B1R-B2R & 189 \\
C & 8 & C1L-C2L & 264 \\
C & 8 & C1R-CR2 & 317 \\
C & 9 & C3L-C4L & 317 \\
D & 10 & D1L-D2L & 90 \\
D & 10 & D2L-D2L & 26 \\
D & 10 & D2L'-D3L & 124 \\
D & 10 & D3L-D4L & 131 \\
D & 10 & D4L-D5L & 100 \\
D & 10 & D1R-DR2 & 135 \\
D & 10 & D2R-D3R & 177 \\
D & 10 & D3R-D4R & 144 \\
D & 11 & D8-D9 & 229 \\
D & 12 & D10-D11 & 163 \\
D & 12 & D11-D12 & 160 \\
\hline & & & \\
\hline
\end{tabular}




\section{Table 4.}

\begin{tabular}{lllll}
\hline & \multicolumn{2}{c}{ Stride } & \multicolumn{2}{c}{ Width } \\
Trackway & Mean & SD & Mean & SD \\
\hline T1 & 186.7 & 26.31 & 47.0 & 2.54 \\
T2 & - & - & 25.0 & - \\
T3 & 172.3 & 22.50 & 28.5 & 6.36 \\
T4 & 332.0 & 2.82 & 43.3 & 2.56 \\
T5 & - & - & 40.6 & 2.56 \\
T6 & 49.7 & 4.13 & 22.7 & 3.40 \\
T7 & 189.0 & - & 31.0 & 0 \\
T8 & 290.5 & 37.47 & 34.2 & 1.70 \\
T9 & 317.0 & - & 32.0 & - \\
T10 & 115.8 & 45.01 & 48.5 & 4.44 \\
T11 & 229.0 & - & 44.0 & 2.82 \\
T12 & 161.5 & 2.12 & 43.3 & 6.65 \\
T13 & - & - & 22.5 & 3.53 \\
\hline
\end{tabular}


Table 5.

\begin{tabular}{llllll}
\hline Assemblage & $\mathbf{N}^{\circ}$ of Trackway & Trace & Width & $\begin{array}{l}\text { Total } \\
\text { lenght }\end{array}$ & $\begin{array}{l}\text { Lenght of the } \\
\text { anterior part }\end{array}$ \\
\hline A & 1 & A1R & 51 & 47 & 27 \\
A & 1 & A1L & - & - & - \\
A & 1 & A2R & 50 & 45 & 27 \\
A & 1 & A2L & - & 43 & - \\
A & 1 & A3L & 41 & 49 & 29 \\
A & 1 & A4L & 46 & - & - \\
A & 2 & A5R & 25 & - & - \\
A & 2 & A5L & - & - & - \\
A & 3 & A6 & - & - & - \\
A & 3 & A7 & - & - & - \\
A & 3 & A8 & 24 & - & - \\
A & 3 & A9 & 33 & 50 & 30 \\
A & 4 & A10 & 41 & 47 & 26 \\
A & 4 & A11 & 43 & 48 & 26 \\
A & 4 & A12 & 46 & - & - \\
A & 5 & A13 & 43 & 45 & 28 \\
A & 5 & A14 & 41 & - & - \\
A & 5 & A15 & 38 & 42 & 26 \\
A & 6 & A16 & 25 & - & - \\
A & 6 & A17 & 29 & - & - \\
A & 6 & A18 & nc & - & - \\
A & 6 & A19 & 21 & - & - \\
A & 6 & A20 & - & - & - \\
A & 6 & A21 & - & - & - \\
A & 6 & A22 & - & - & - \\
A & 6 & A23 & 19 & - & - \\
A & 6 & A24 & 23 & - & - \\
A & 6 & A25 & 20 & - & - \\
A & 6 & A26 & 22 & - & - \\
B & 7 & B1R & 31 & 39 & 16 \\
B & 7 & B2R & - & - & - \\
B & 7 & B2L & 31 & 42 & 20 \\
B & 7 & B3L & - & 39 & - \\
B & - & B4 & 27 & 28 & 10 \\
B & - & B5 & 30 & 33 & 14 \\
B & - & B6 & 27 & - & 12 \\
B & - & B7 & 21 & - & - \\
B & - & B8 & 22 & 17 & 8 \\
B & - & B9 & - & - & - \\
B & - & B10 & 18 & 32 & 12 \\
B & - & & & & \\
B & - & - & 26 & 12 \\
B & - & - & - & - \\
\hline
\end{tabular}

\begin{tabular}{|c|c|c|c|c|c|}
\hline Assemblage & $\mathbf{N}^{\circ}$ of Trackway & Trace & Width & $\begin{array}{l}\text { Total } \\
\text { lenght }\end{array}$ & $\begin{array}{l}\text { Lenght of the } \\
\text { anterior part }\end{array}$ \\
\hline$\overline{\mathrm{B}}$ & - & B14 & 24 & 30 & 10 \\
\hline $\mathrm{B}$ & - & B15 & 30 & 28 & 12 \\
\hline B & - & B16 & 33 & - & 14 \\
\hline $\mathrm{B}$ & - & B17 & 29 & - & 14 \\
\hline $\mathrm{B}$ & - & B19 & - & - & - \\
\hline $\mathrm{B}$ & - & B18 & 28 & 30 & 15 \\
\hline B & - & B20 & 32 & 30 & 13 \\
\hline B & - & B21 & 24 & 34 & 16 \\
\hline B & - & B22 & 25 & 30 & 9 \\
\hline B & - & B23 & 28 & 34 & 14 \\
\hline B & - & B24 & 25 & 34 & 11 \\
\hline B & - & $\mathrm{B} 25$ & 27 & 19 & 14 \\
\hline B & - & B26 & 22 & 38 & 17 \\
\hline $\mathrm{C}$ & 8 & $\mathrm{C} 1 \mathrm{~L}$ & 36 & - & 12 \\
\hline $\mathrm{C}$ & 8 & $\mathrm{C} 1 \mathrm{R}$ & 35 & - & 12 \\
\hline $\mathrm{C}$ & 8 & $\mathrm{C} 2 \mathrm{~L}$ & 32 & - & 9 \\
\hline $\mathrm{C}$ & 8 & $\mathrm{C} 2 \mathrm{R}$ & 34 & - & 10 \\
\hline $\mathrm{C}$ & 9 & $\mathrm{C} 3 \mathrm{~L}$ & - & 58 & 25 \\
\hline $\mathrm{C}$ & 9 & $\mathrm{C} 4 \mathrm{R}$ & 32 & 53 & 22 \\
\hline $\mathrm{C}$ & 9 & $\mathrm{C} 4 \mathrm{~L}$ & - & 60 & 26 \\
\hline $\mathrm{C}$ & - & $\mathrm{C} 5$ & 38 & 65 & 27 \\
\hline $\mathrm{C}$ & - & C6 & - & 35 & 15 \\
\hline $\mathrm{D}$ & 10 & D1R & 45 & - & - \\
\hline $\mathrm{D}$ & 10 & D1L & 43 & 41 & 22 \\
\hline $\mathrm{D}$ & 10 & $\mathrm{D} 2 \mathrm{R}$ & 42 & - & 26 \\
\hline $\mathrm{D}$ & 10 & $\mathrm{D}^{\prime} \mathrm{L}^{\prime}$ & 50 & - & 25 \\
\hline $\mathrm{D}$ & 10 & $\mathrm{D} 2 \mathrm{~L}^{\prime}$ & 49 & - & 25 \\
\hline D & 10 & $\mathrm{D} 3 \mathrm{R}$ & 48 & - & - \\
\hline D & 10 & D3L & 53 & 52 & 27 \\
\hline D & 10 & D4R & - & - & - \\
\hline D & 10 & D4L & 53 & - & - \\
\hline D & 10 & D5L & 54 & 61 & 33 \\
\hline D & 13 & D6 & 25 & 36 & 17 \\
\hline D & 13 & D7 & 20 & - & 17 \\
\hline D & 11 & D8 & 46 & 63 & 24 \\
\hline D & 11 & D9 & 42 & 45 & 20 \\
\hline D & 12 & D10 & 39 & - & 15 \\
\hline D & 12 & D11 & 51 & - & 21 \\
\hline D & 12 & D12 & 40 & - & 16 \\
\hline D & - & D13 & 59 & - & 32 \\
\hline $\mathrm{D}$ & - & $\mathrm{D} 14$ & 35 & - & 20 \\
\hline $\mathrm{D}$ & - & $\mathrm{D} 15$ & 40 & - & 19 \\
\hline D & - & D16 & - & - & - \\
\hline
\end{tabular}


Table 6.

\begin{tabular}{|c|c|c|c|}
\hline Isolated trace & Width & Total lenght & $\begin{array}{l}\text { Lenght of the } \\
\text { anterior part }\end{array}$ \\
\hline$\overline{\mathrm{I} 1 \mathrm{~A}}$ & - & - & 35 \\
\hline I1B & 53 & - & 31 \\
\hline $\mathrm{I} 1 \mathrm{C}$ & - & - & - \\
\hline I1D & 52 & 66 & 32 \\
\hline $\mathrm{I} 2$ & 58 & 68 & 32 \\
\hline $\mathrm{I} 3$ & 57 & - & 29 \\
\hline $\mathrm{I} 4$ & 39 & - & 18 \\
\hline I5 & 37 & - & 14 \\
\hline I6 & - & - & - \\
\hline I7 & 51 & 58 & 22 \\
\hline I8A & 42 & - & 28 \\
\hline I8B & 53 & 67 & 28 \\
\hline $\mathrm{I} 8 \mathrm{C}$ & 47 & 66 & 29 \\
\hline I9A & 31 & 49 & 19 \\
\hline I9B & 29 & - & 12 \\
\hline $\mathrm{I} 10$ & 38 & 65 & 25 \\
\hline I11 & 37 & 64 & 28 \\
\hline $\mathrm{I} 12$ & 42 & 69 & 29 \\
\hline $\mathrm{I} 13$ & - & - & - \\
\hline $\mathrm{I} 14$ & 39 & 45 & 11 \\
\hline $\mathrm{I} 15$ & 21 & 34 & 13 \\
\hline I16 & 36 & 49 & 23 \\
\hline $\mathrm{I} 17$ & 56 & 68 & 30 \\
\hline $\mathrm{I} 18$ & 25 & 37 & 12 \\
\hline I19 & 22 & 20 & 10 \\
\hline $\mathrm{I} 20$ & 41 & - & 19 \\
\hline $\mathrm{I} 21$ & 31 & 42 & 17 \\
\hline $\mathrm{I} 22$ & 32 & - & 18 \\
\hline $\mathrm{I} 23$ & - & - & - \\
\hline $\mathrm{I} 24 \mathrm{~A}$ & 39 & 41 & 16 \\
\hline $\mathrm{I} 24 \mathrm{~B}$ & 27 & 42 & 14 \\
\hline $\mathrm{I} 25$ & 29 & 36 & 13 \\
\hline $\mathrm{I} 26$ & 45 & - & 17 \\
\hline $\mathrm{I} 27$ & 37 & 41 & 21 \\
\hline I29 & 44 & 46 & 20 \\
\hline $\mathrm{I} 30$ & 30 & - & 15 \\
\hline I31 & - & - & - \\
\hline $\mathrm{I} 36 \mathrm{~A}$ & 33 & 46 & 22 \\
\hline $\mathrm{I} 36 \mathrm{~B}$ & 33 & 41 & 17 \\
\hline I37A & 50 & 57 & 30 \\
\hline I37B & 52 & 68 & 27 \\
\hline I38A & 29 & 41 & 18 \\
\hline $\mathrm{I} 38 \mathrm{~B}$ & 30 & 42 & 20 \\
\hline I39A & 21 & - & 10 \\
\hline I39B & 21 & 24 & 9 \\
\hline $\mathrm{I} 40$ & 31 & 38 & 14 \\
\hline I41 & 19 & 23 & 9 \\
\hline I42 & 27 & 39 & 15 \\
\hline I43 & 20 & 25 & 12 \\
\hline I44 & 19 & 20 & 7 \\
\hline $\mathrm{I} 45$ & 22 & 24 & 8 \\
\hline $\mathrm{I} 46 \mathrm{~A}$ & 11 & 11 & 6 \\
\hline I $46 \mathrm{~B}$ & 11 & - & 5 \\
\hline $\mathrm{I} 46 \mathrm{C}$ & 24 & 25 & 10 \\
\hline I47 & 21 & 19 & 8 \\
\hline I48 & 34 & 32 & 14 \\
\hline I49 & 50 & 69 & 28 \\
\hline I50 & 20 & 23 & 8 \\
\hline I51 & 30 & 31 & 12 \\
\hline $\mathrm{I} 52 \mathrm{~A}$ & 16 & - & 5 \\
\hline I52B & 16 & - & 5 \\
\hline
\end{tabular}




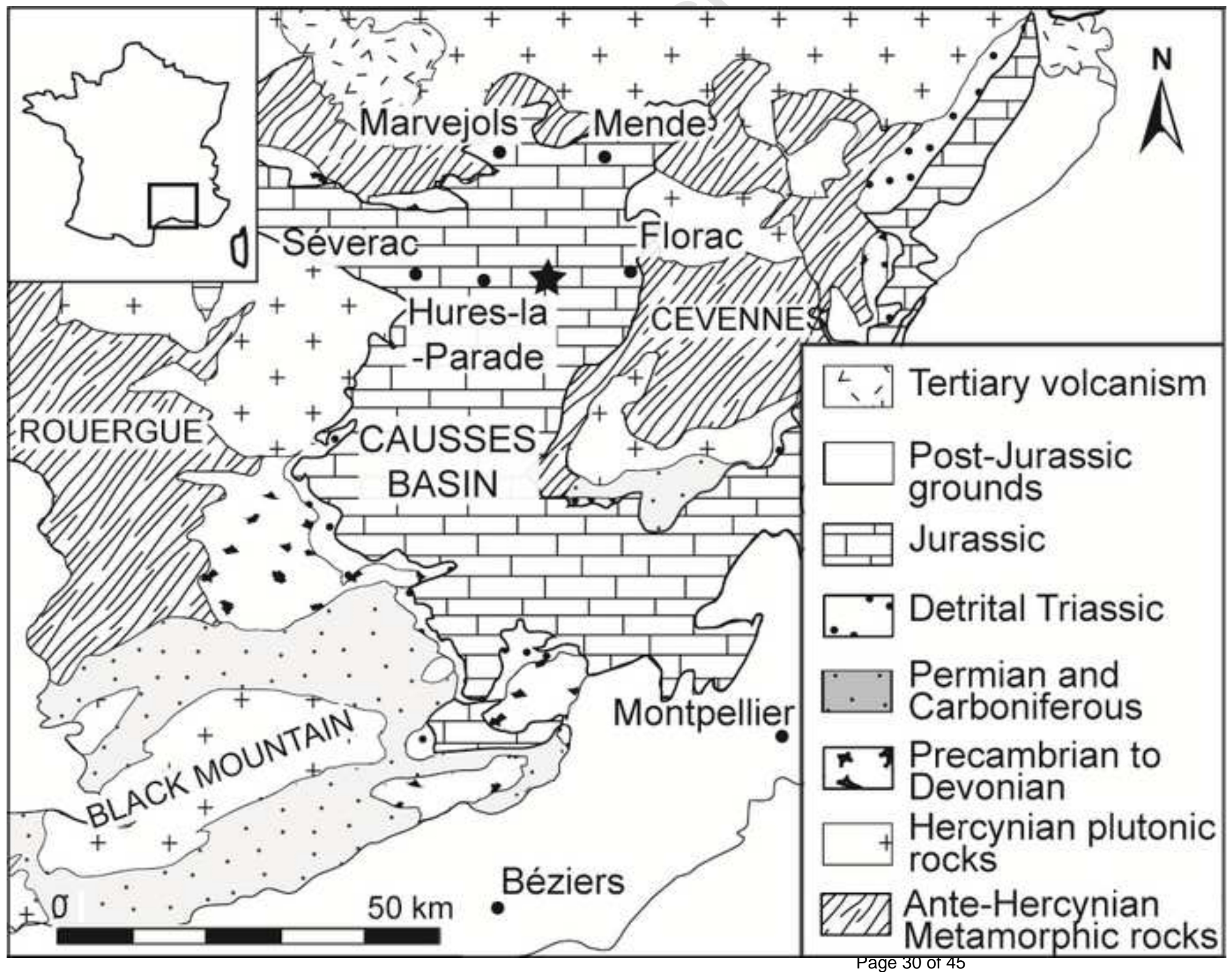




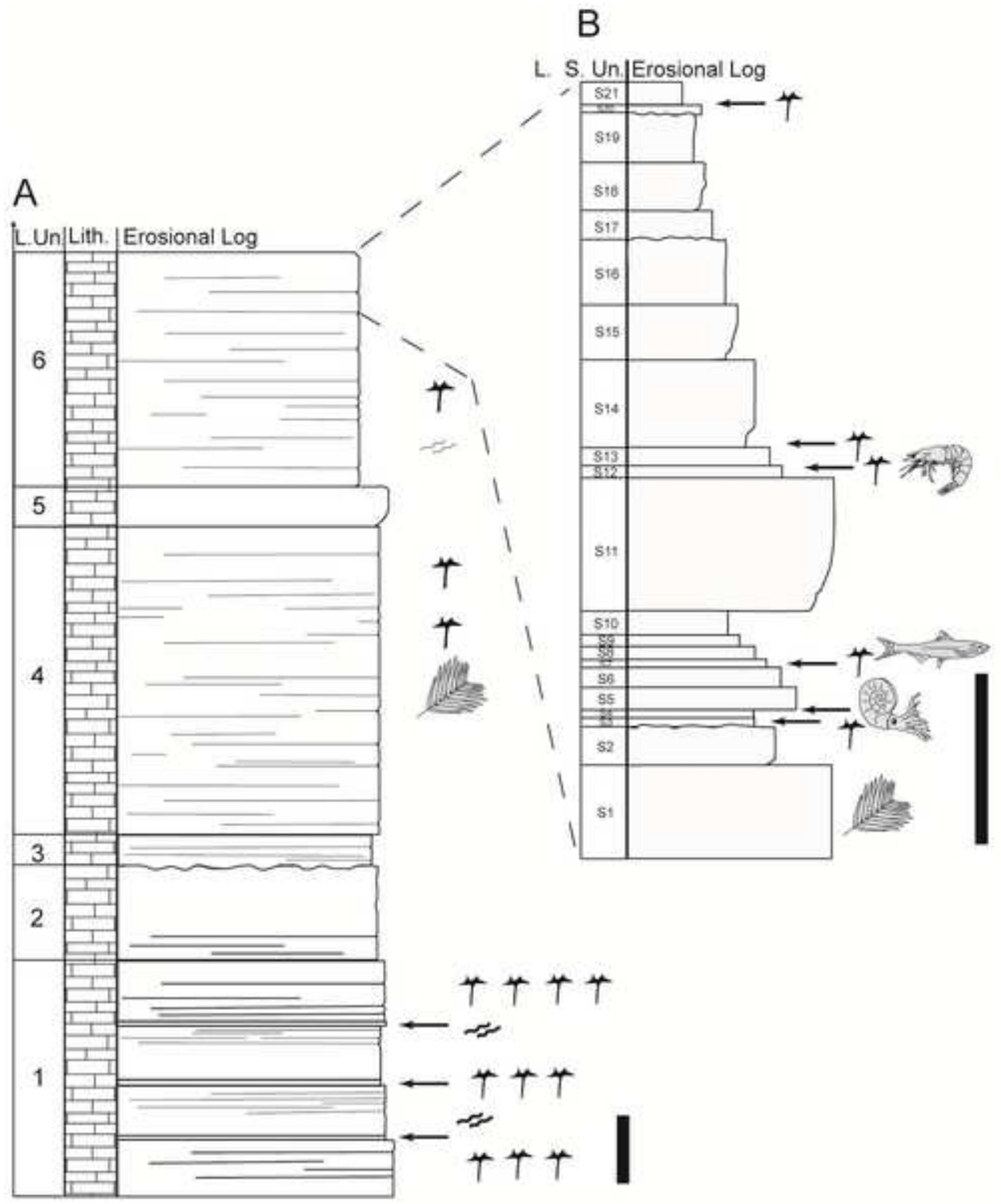

\section{Sublithographic limestone}

Terrestrial plants
م Cochlichnus

Fishes Ammonites Crustaceans 
A

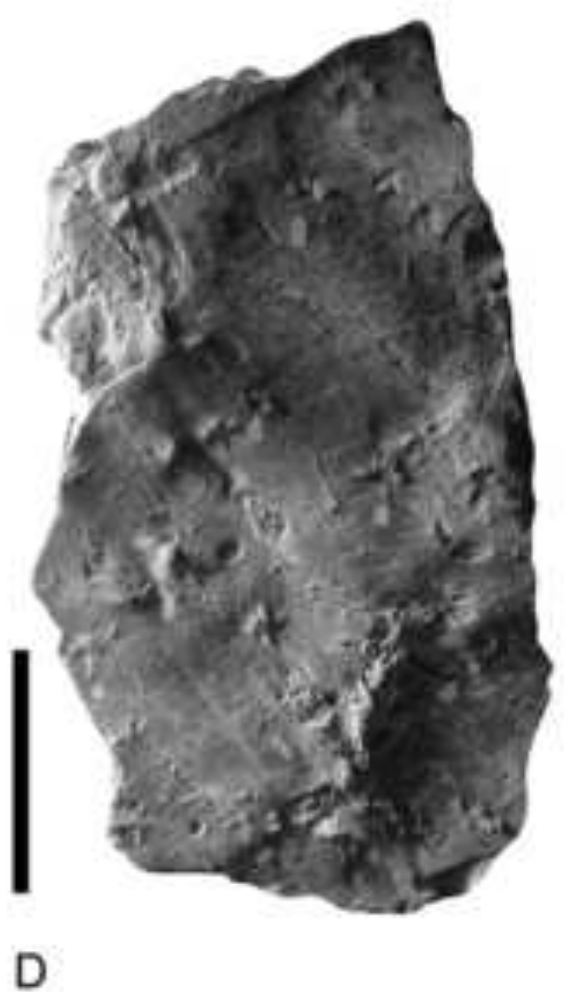

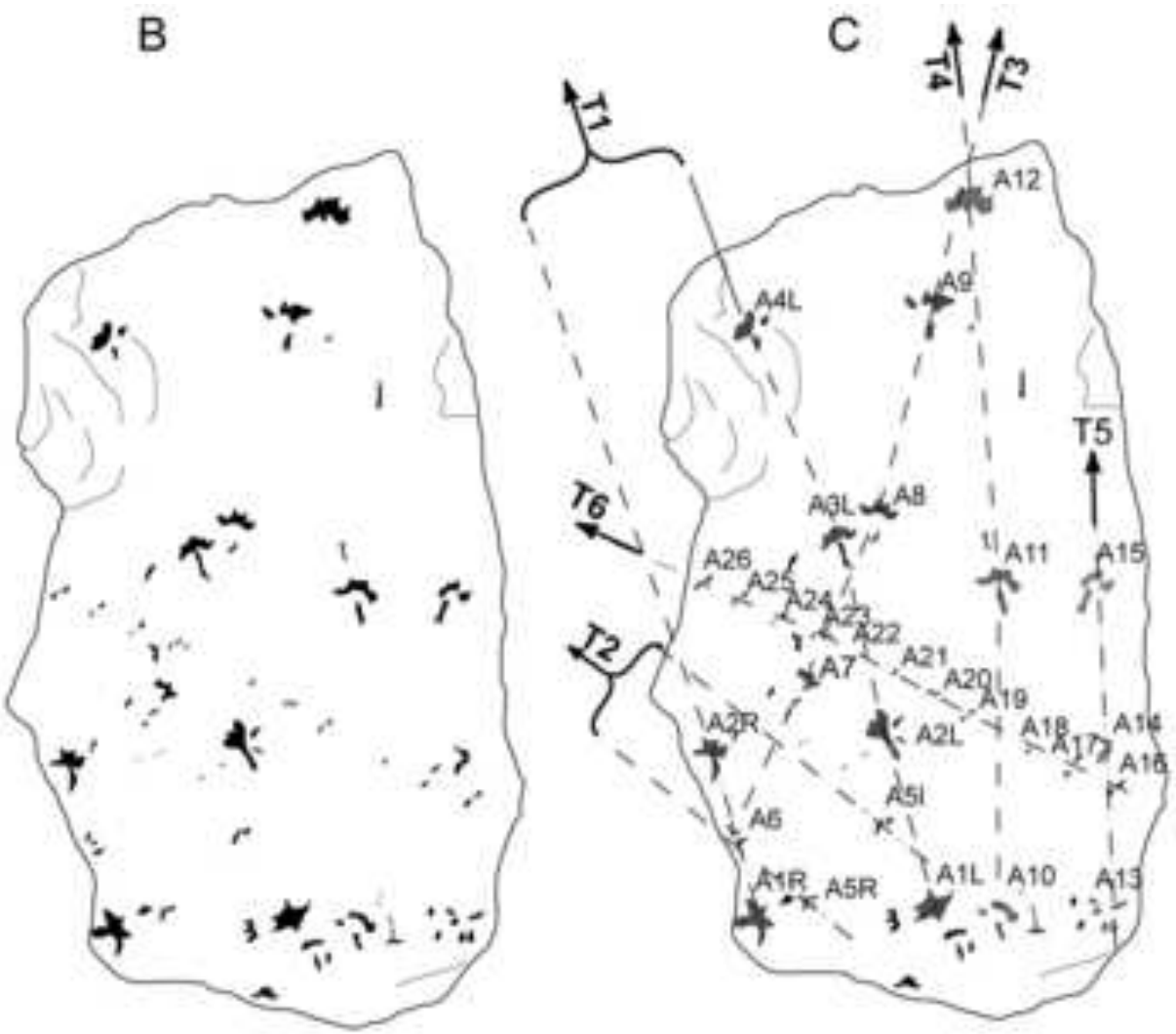

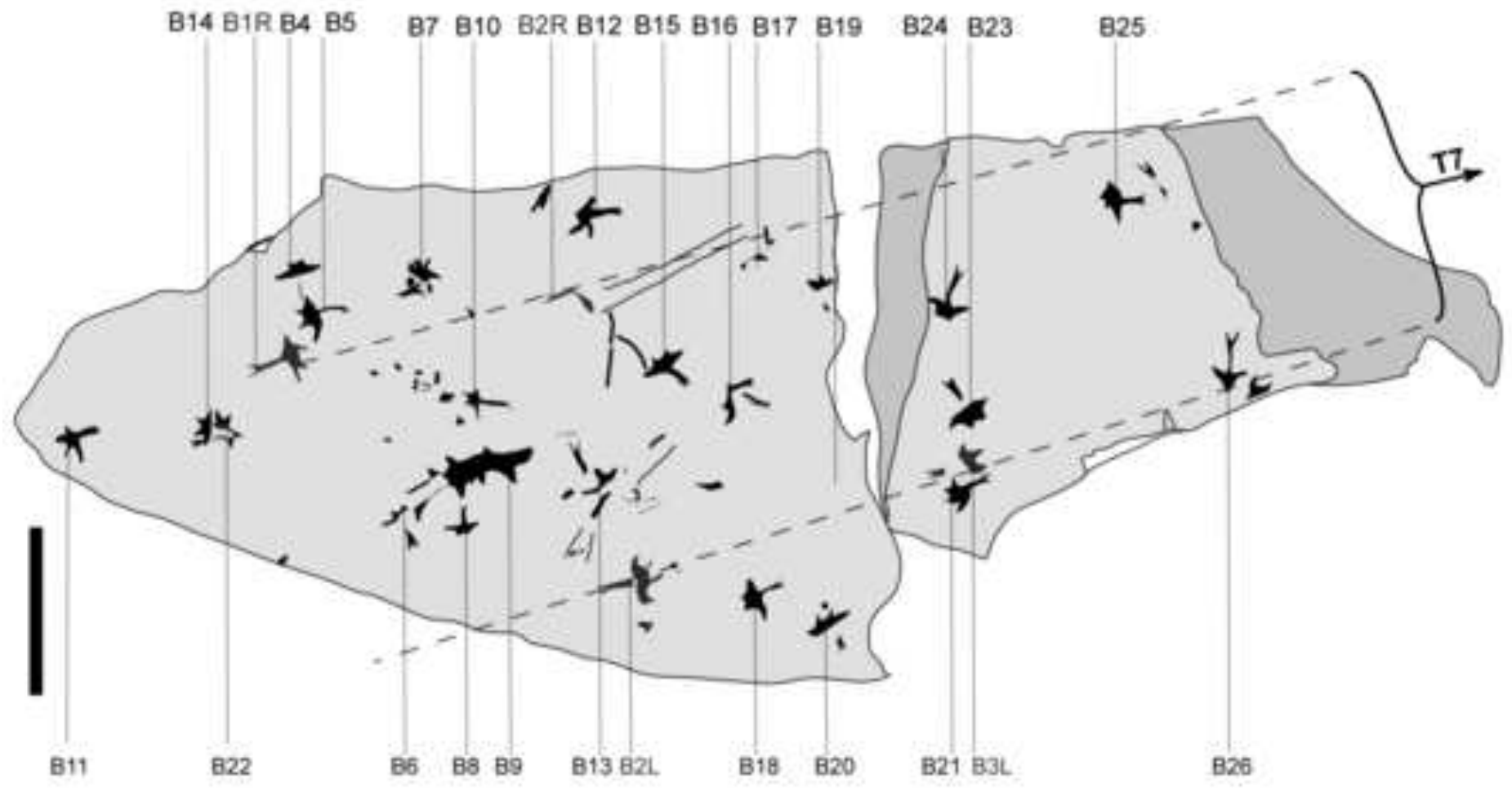


A

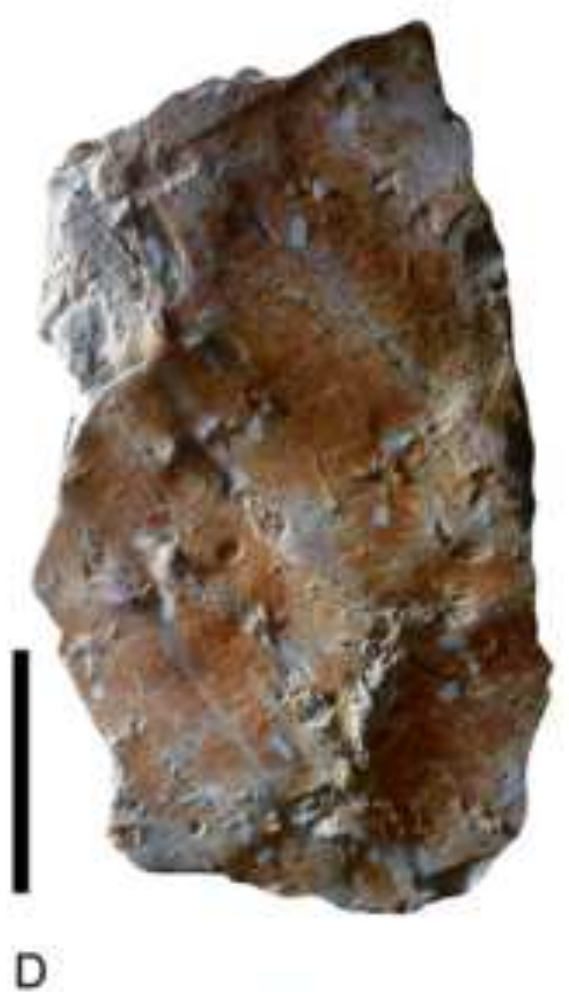

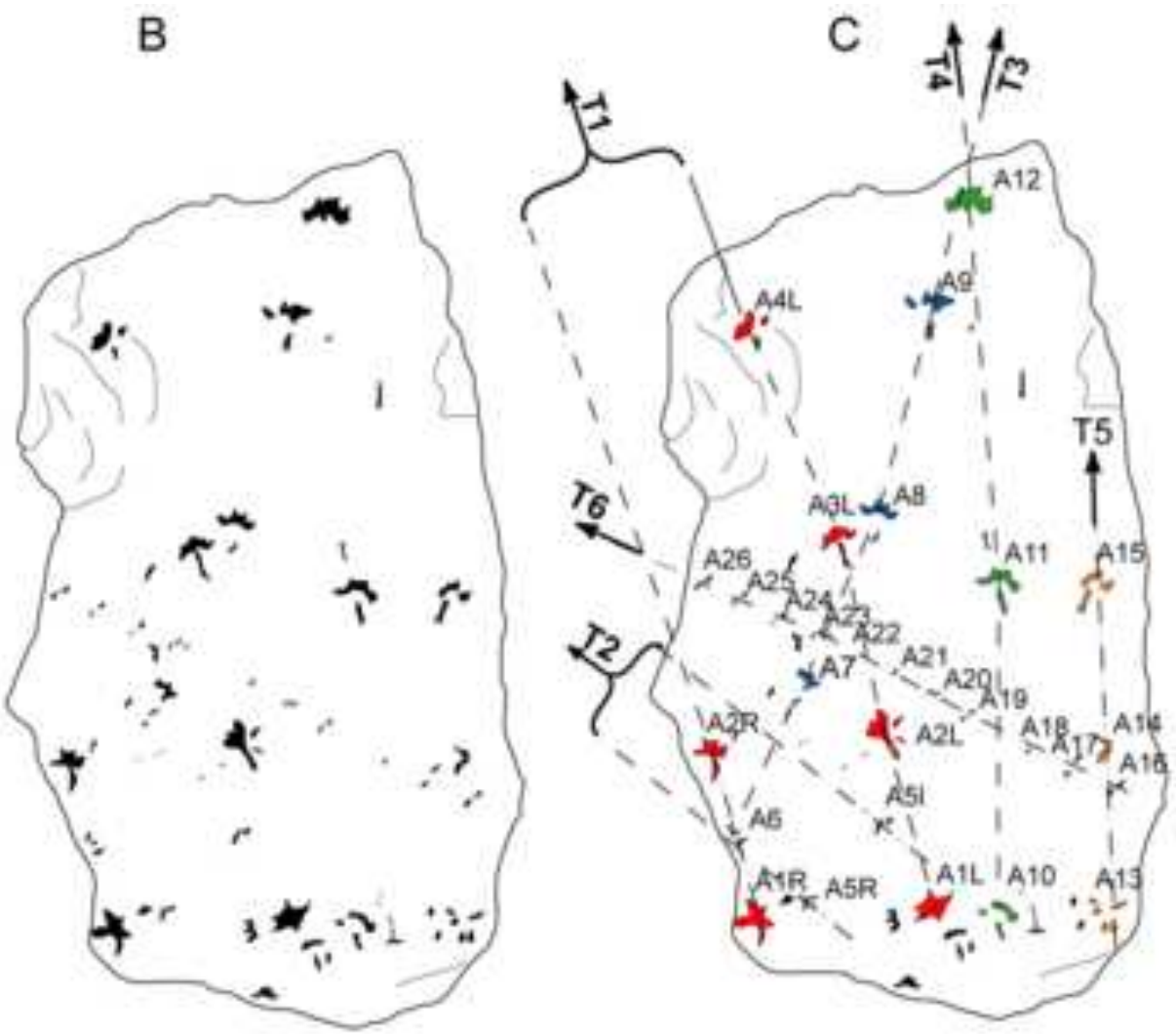

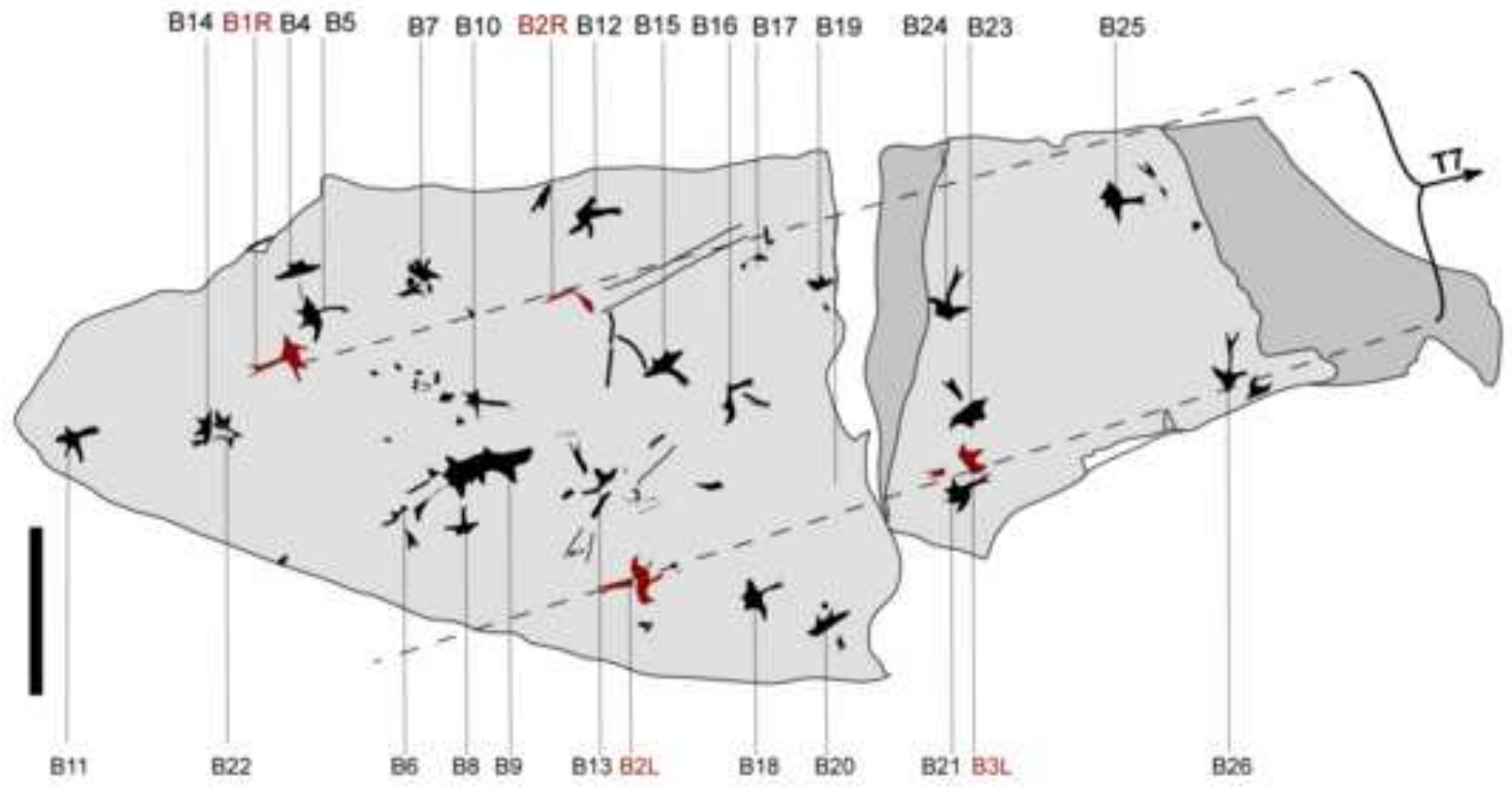



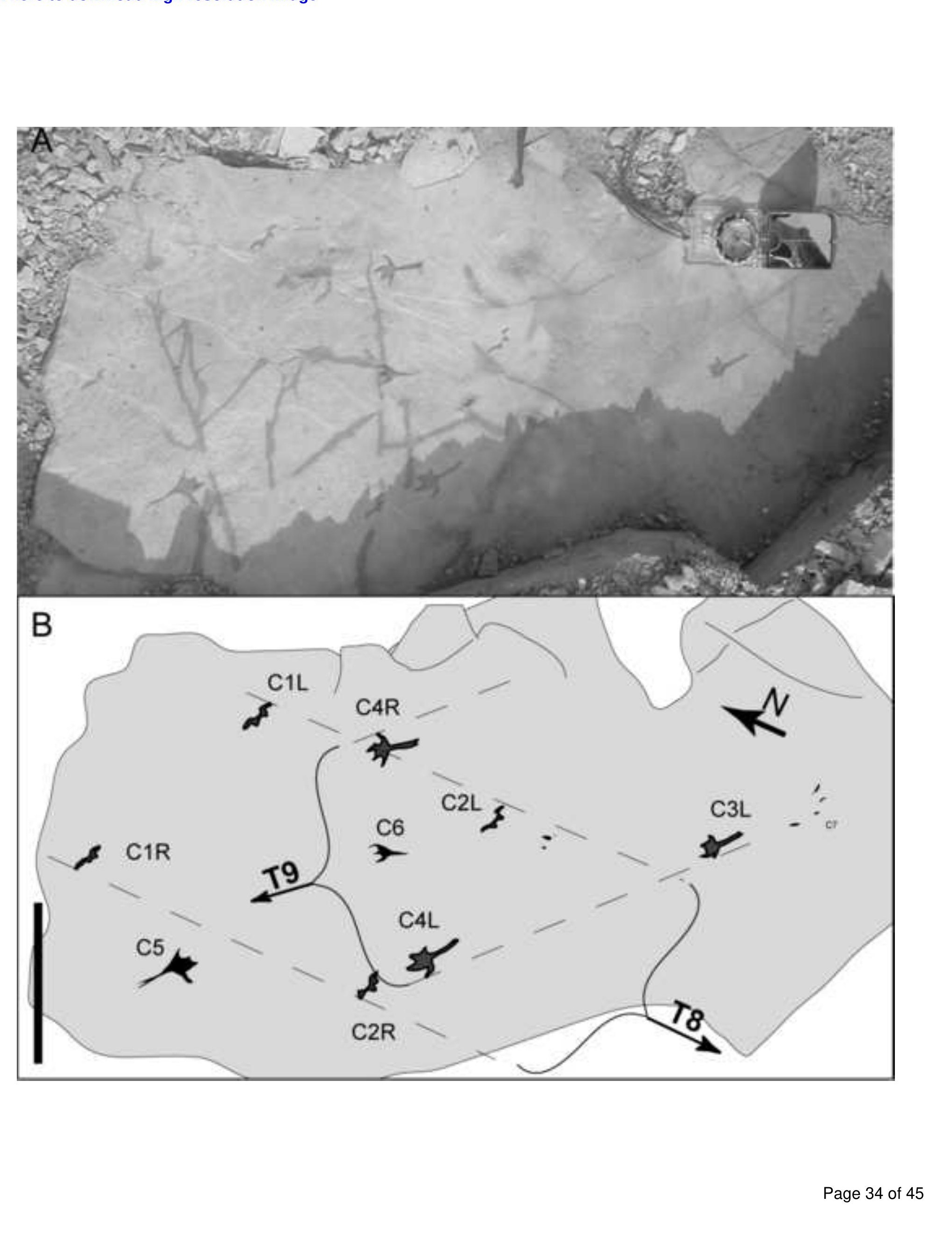

Figure $4 \mathrm{B \& W}$
Click here to download high resolution image

西

\section{Page 34 of 45}


Figure 4 color

Click here to download high resolution image

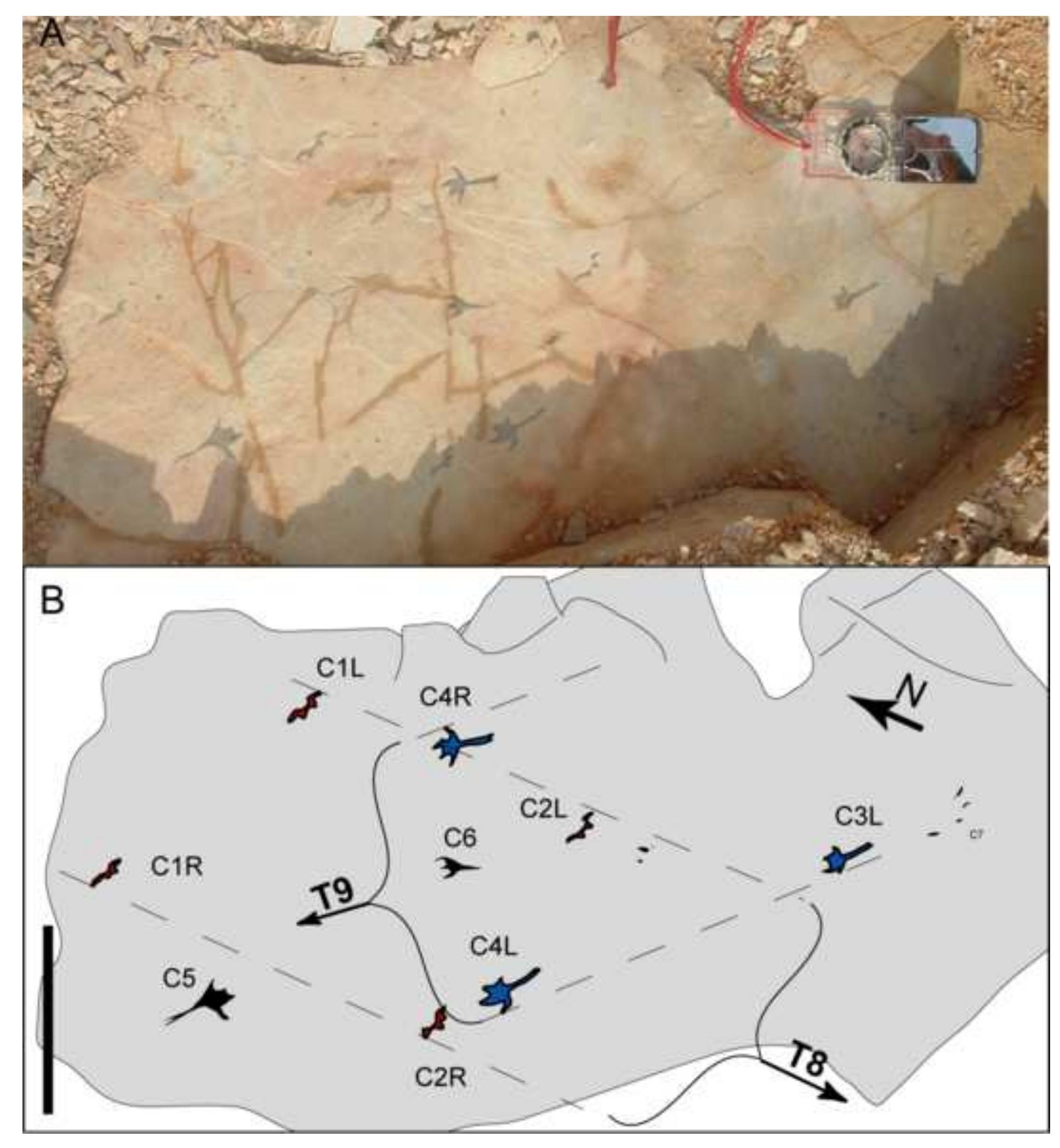

B 
Figure 5 B\&W
Click here to download high resolution image
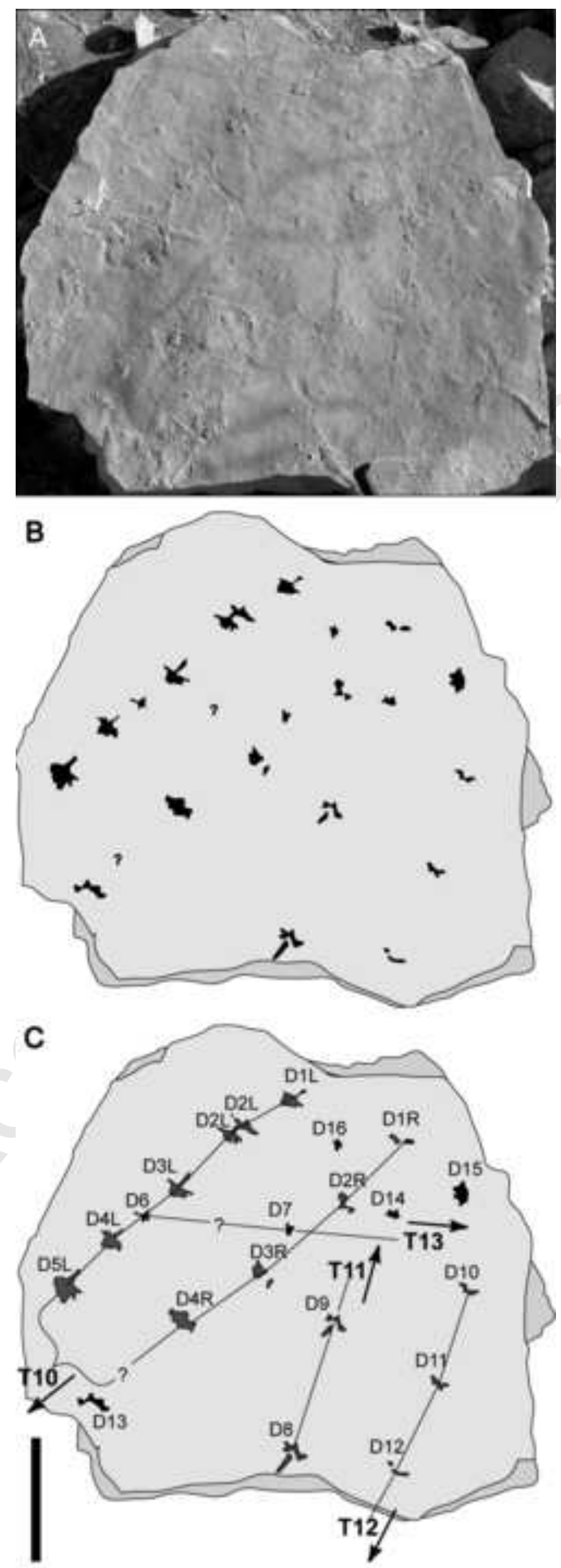
Figure 5 color
Click here to download high resolution image
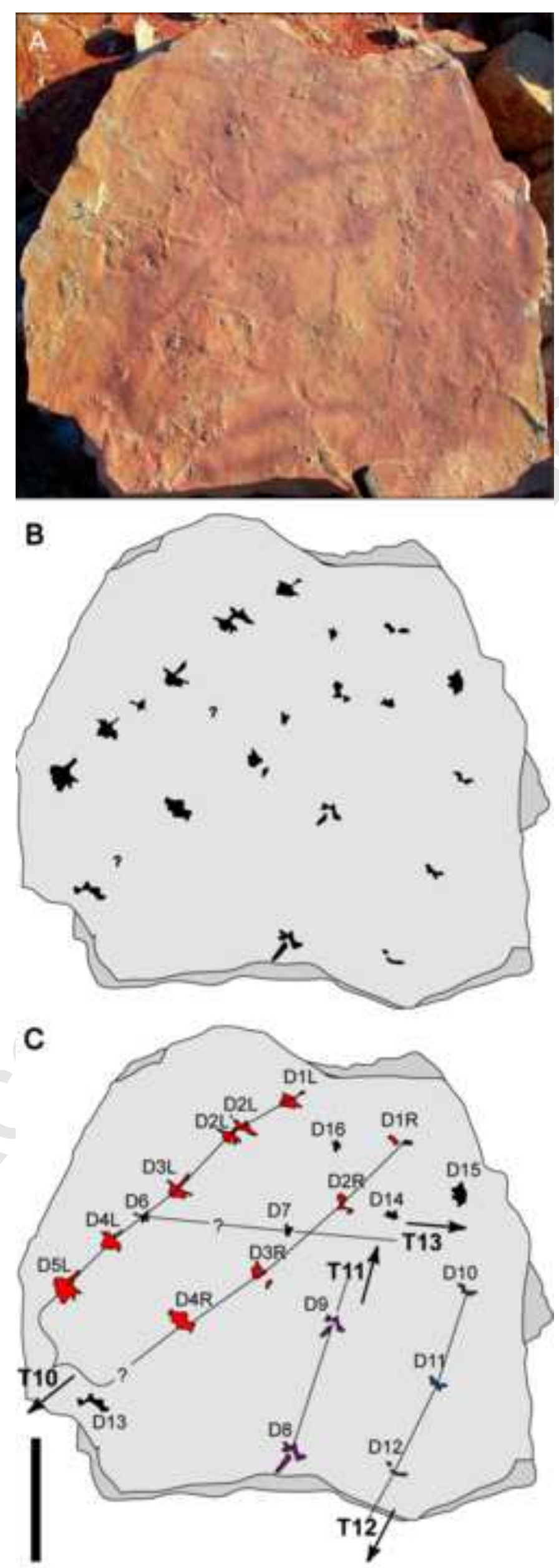


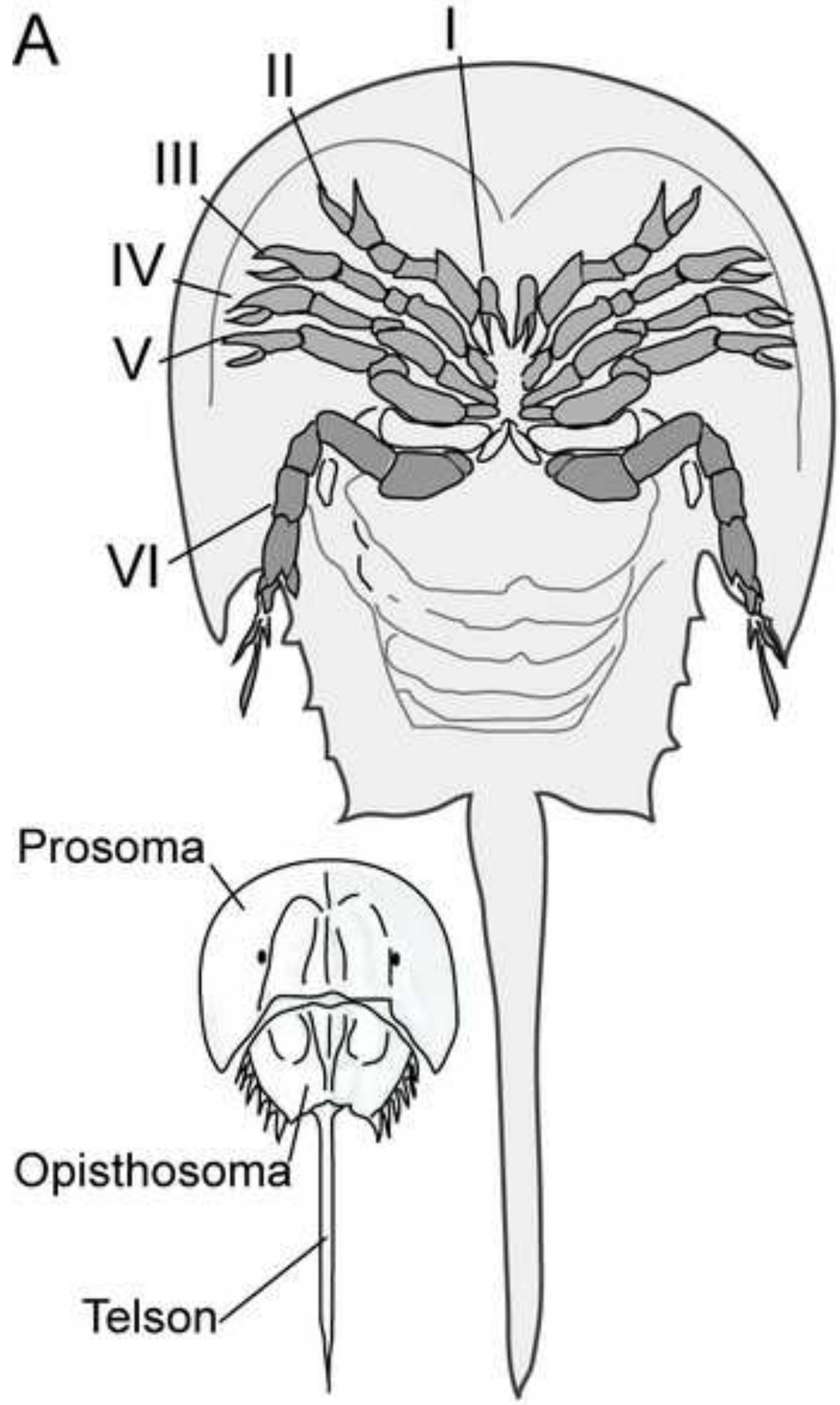

B

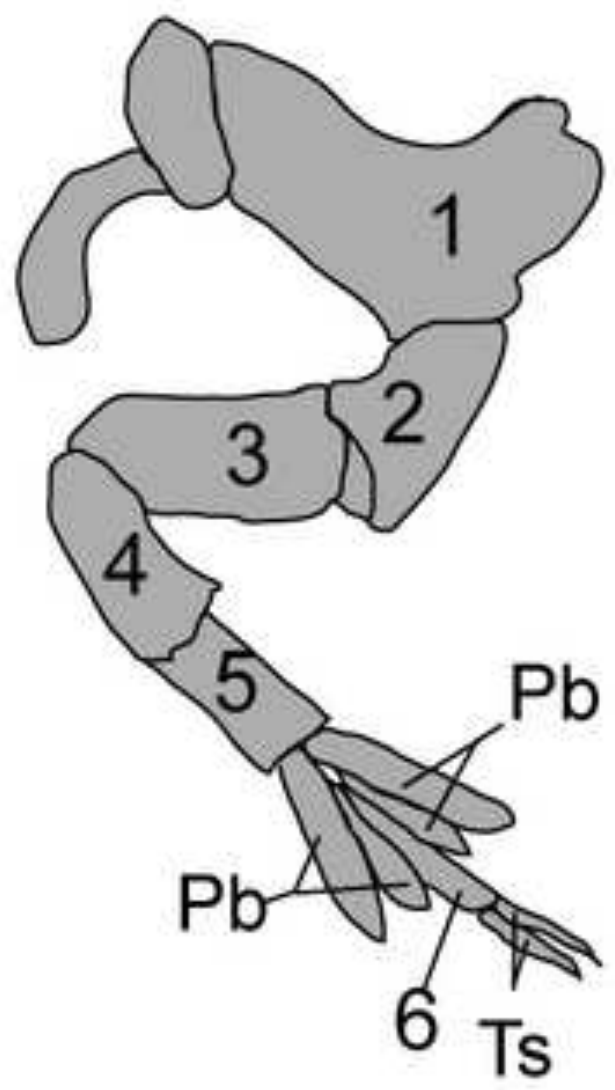

C

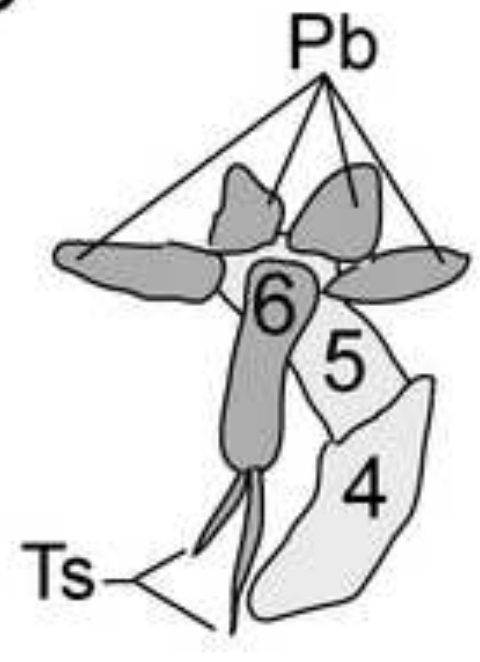




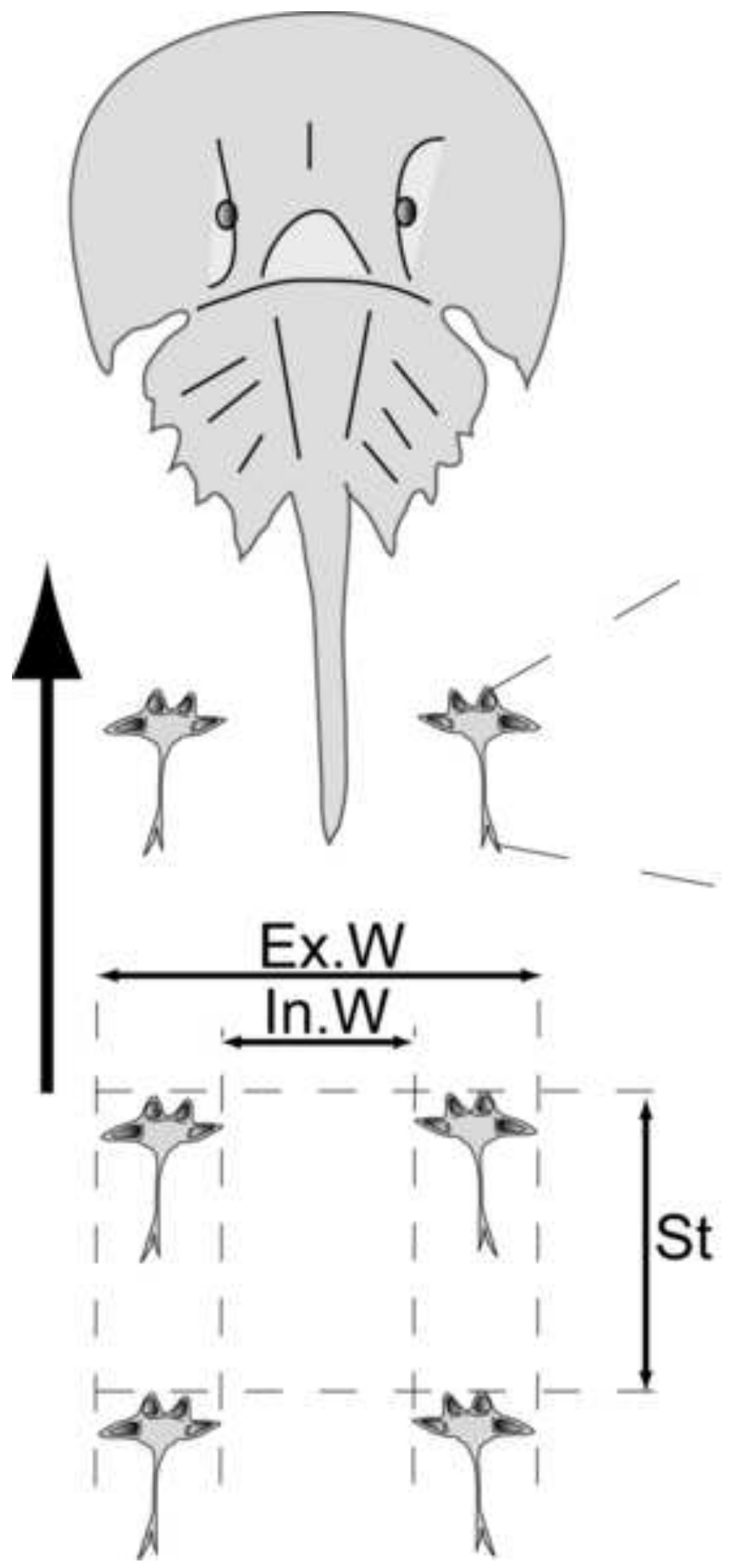


Click here to download high resolution image
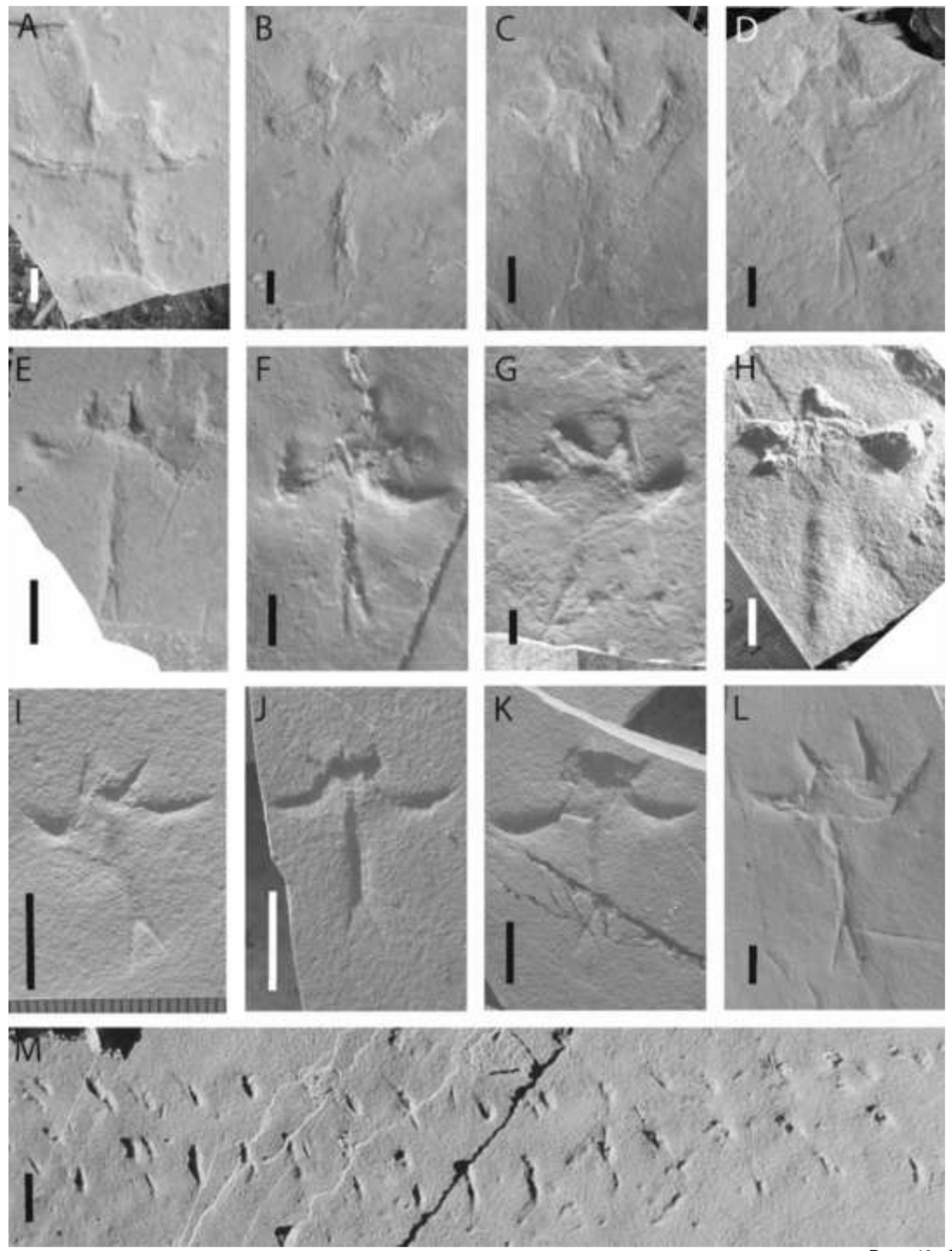
Click here to download high resolution image
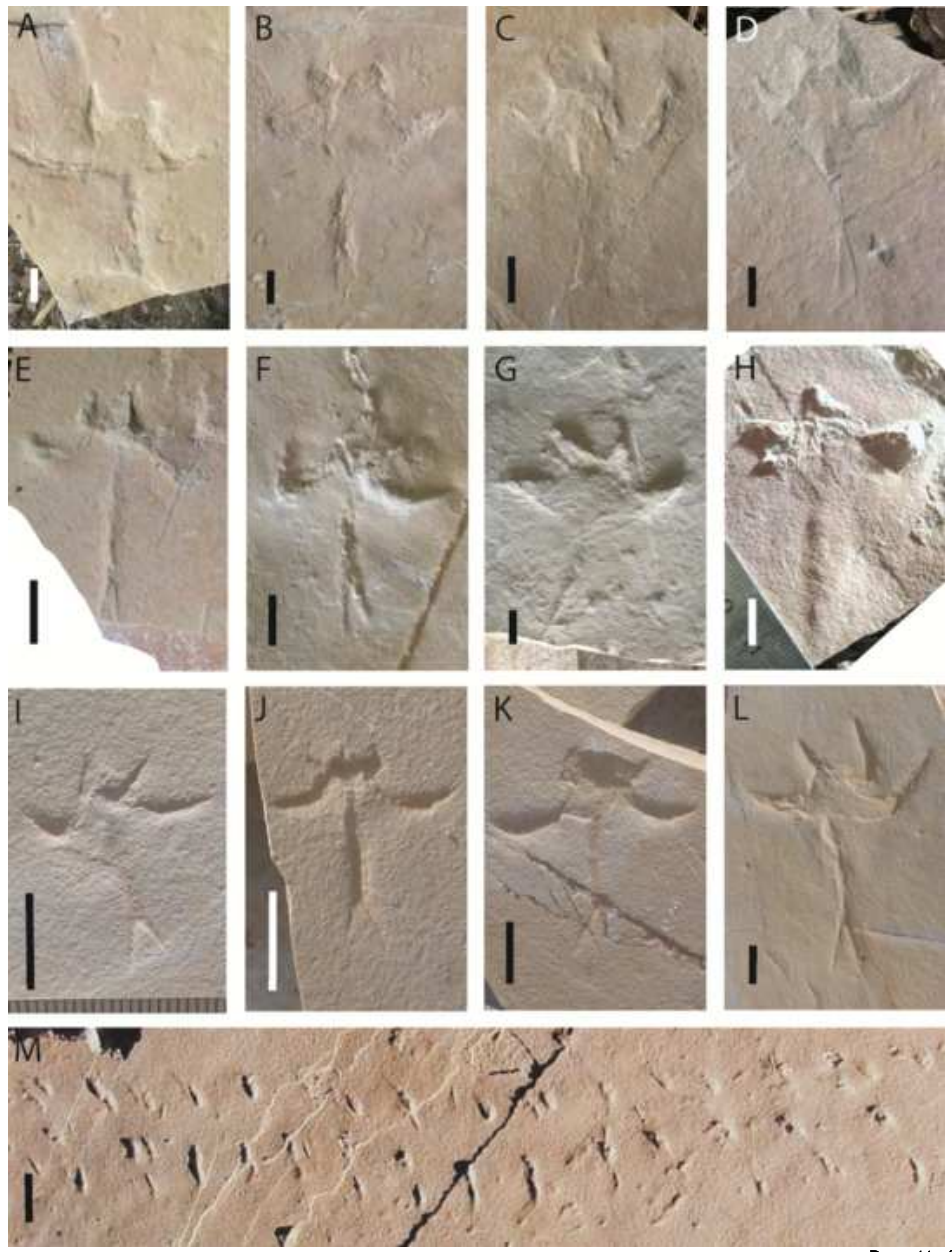


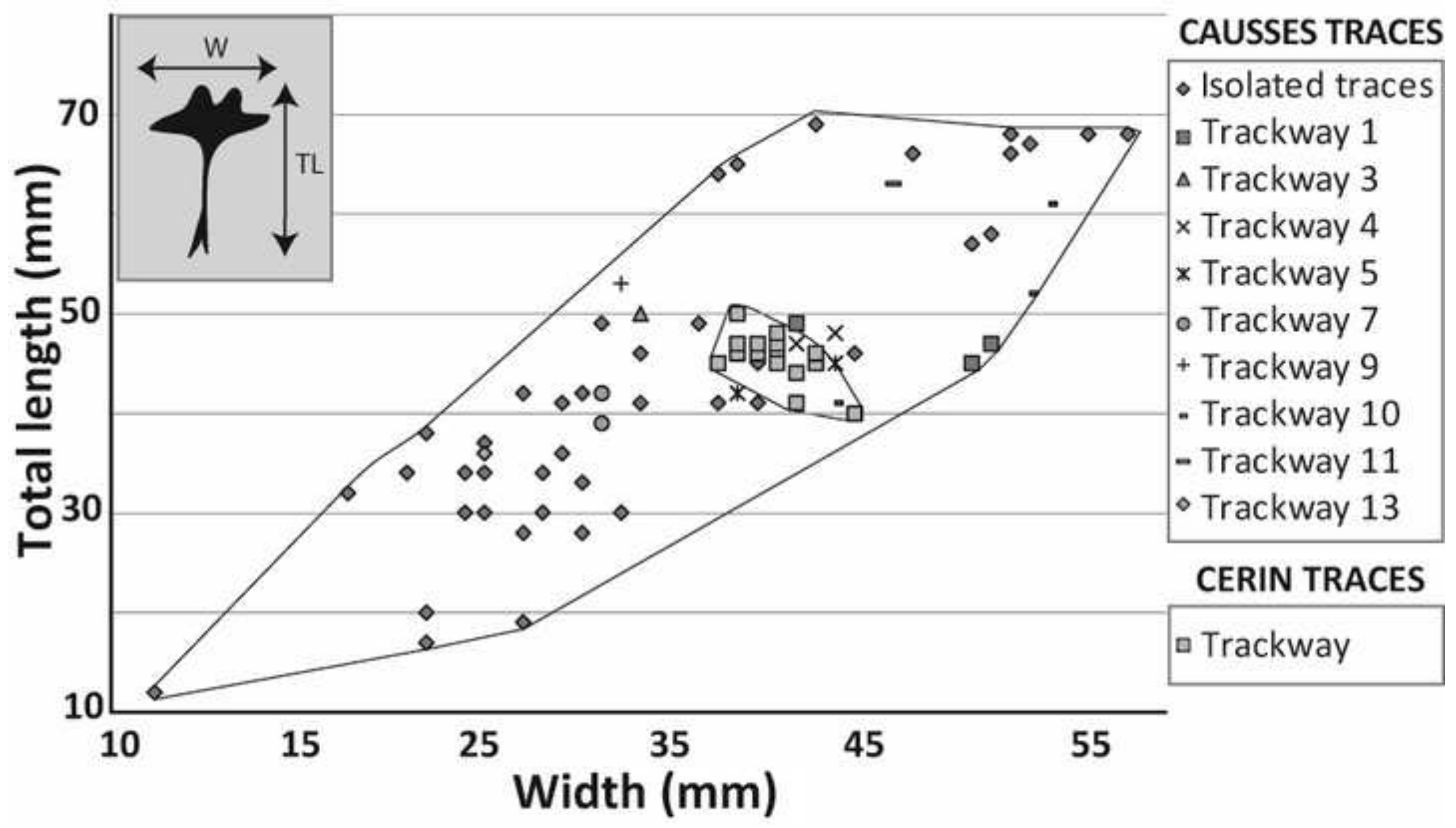




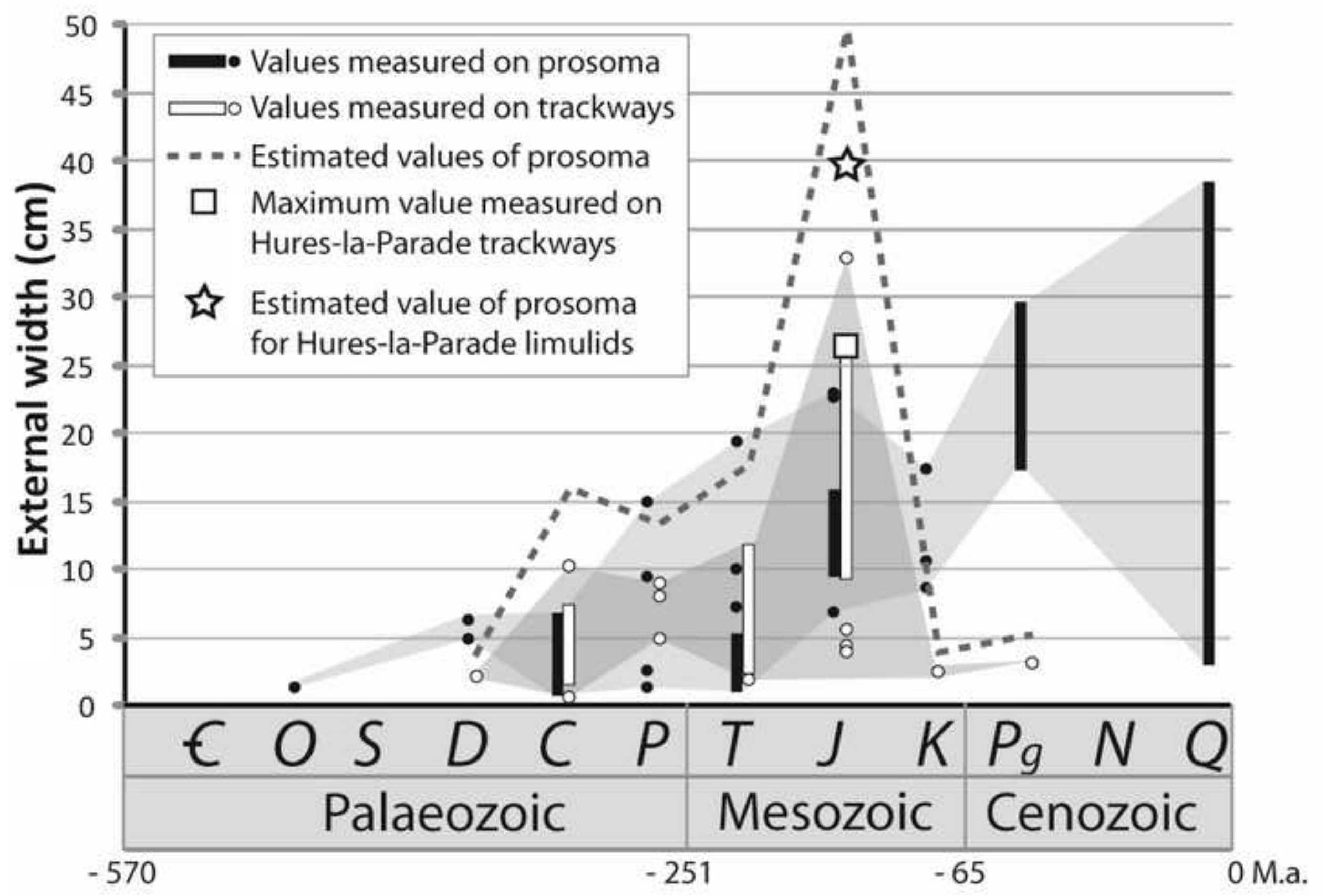




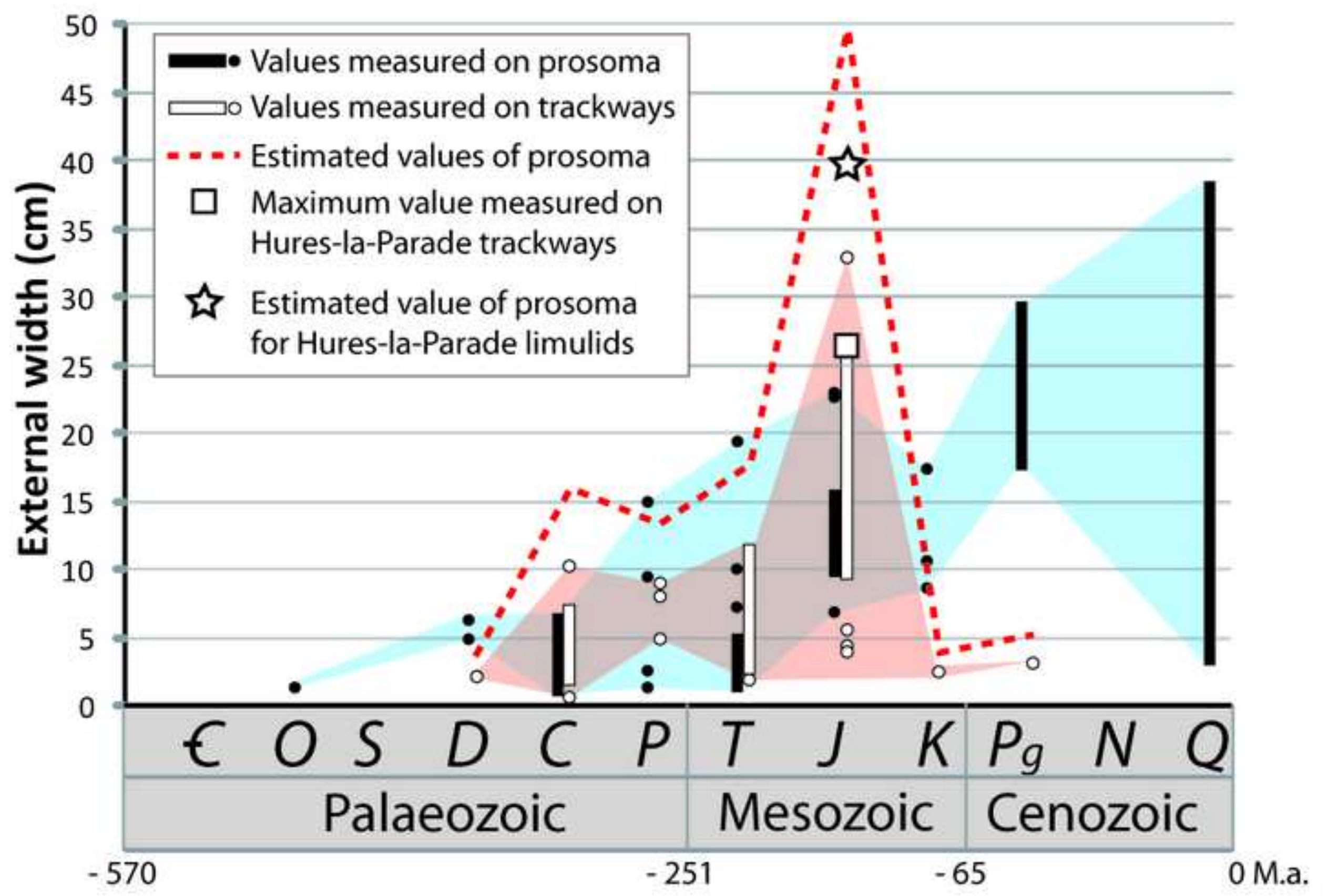




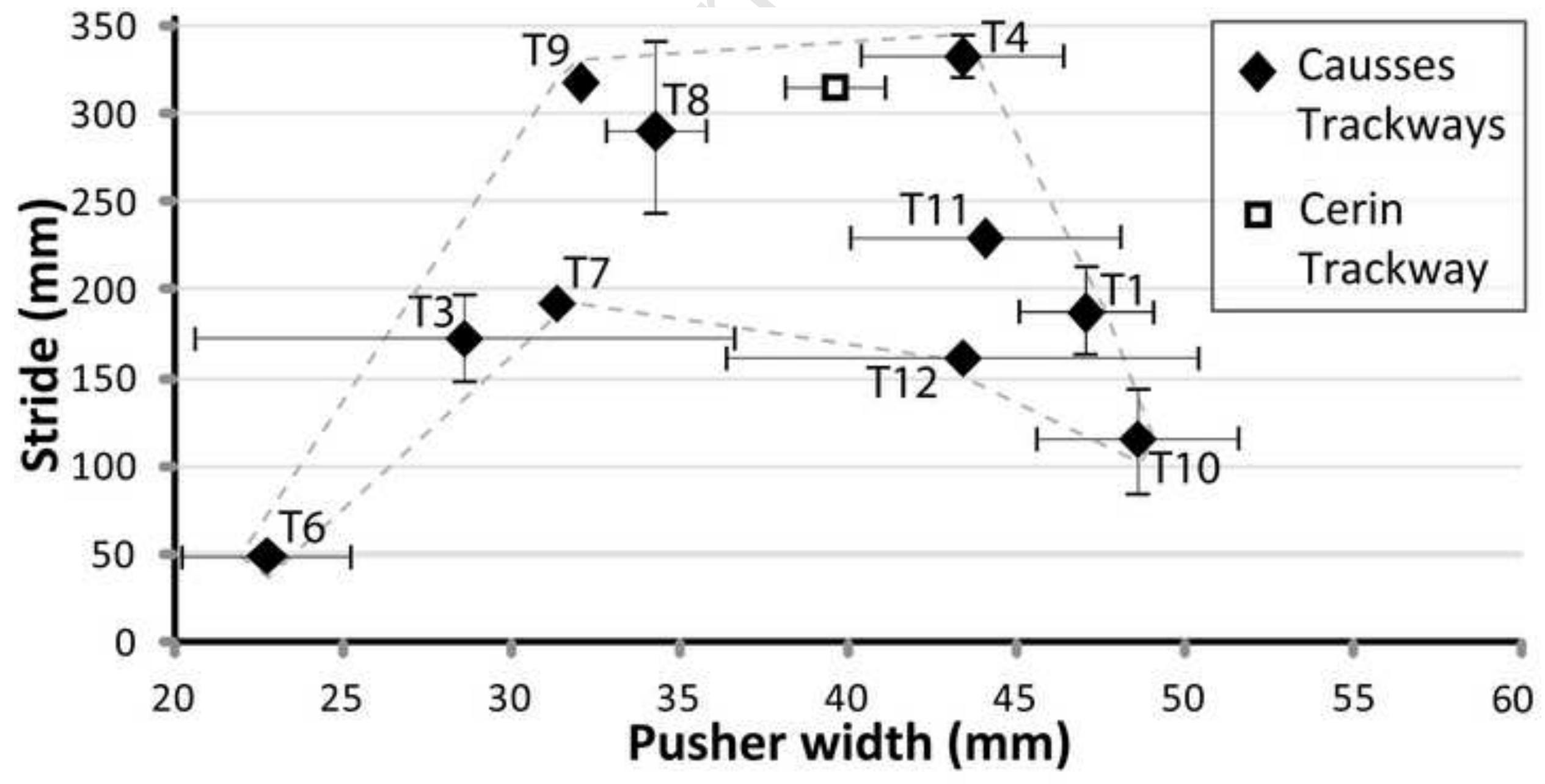

